"RECORDS ADMINISTRATION

DP-1606

R0139076

\title{
DESCRIPTION OF DWPF REFERENCE WASTE FORM AND CANISTER
}

R. G. BAXTER

Long-Term Design Liaison:

Waste Management Programs
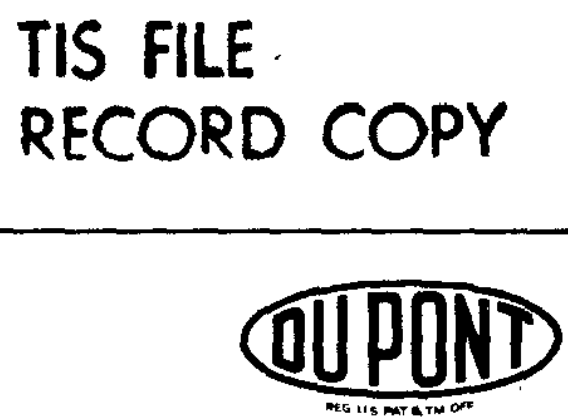

E. I. du Pont de Nemours \& Co. Savannah River Laboratory

Aiken, SC 29808 


\section{Disclaimer}

This report was prepared by E. I. du Pont de Nemours and Company (Ou Pont) for the United States Department of Energy under Contract DE-ACO9-76SR00001 and is an account of work performed under that Contract. Neither the United States, the United States Department of Energy nor Du Pont, nor any of their employees, makes any warranty, express or implied, or assumes any legal liability or responsibility for the accuracy, completeness, or usefulness of any information, apparatus, product, or process disclosed herein, or represents that its use will not infringe privately owned rights. Reference herein to any specific commerical product, process, or service by trade name, mark, manufacturer, or otherwise does not necessarily constitute or imply endorsement, recommendation, or favoring of same by Du Pont or by the United States Government or any agency thereof. The views and opinions of authors expressed herein do not necessarily state or reflect those of the United States Government or any agency thereof.

Printed in the United States of America

Available from

National Techrical Information Service

U. S. Department of Commerce

5285 Port Royal Road

Springfield, Virginia 22161

Price: Printed Copy A04; Microfiche A01 


\section{DESCRIPTION OF DWPF REFERENCE WASTE FORM AND CANISTER}

R. G. BAXTER

Approved by

J. B. Me11en, Superintendent

R. Maher, Program Manager

Waste Management Programs

Publication Date: June 1981

\section{E. I. du Pont de Nemours \& Co. Savannah River Laboratory Aiken, SC 29808} PREPARED FOR THE U. S. DEPARTMENT OF ENERGY UNDER CONTRACT DE-ACO9.76SR00001 
This document describes the reference waste form and canister for the Defense Waste Processing Facility (DWPF). The facility is planned for location at the Savannah River Plant in Aiken, SC, and is schedıled for construction authorization during FY-1983.

The reference canister is fabricated of $24 \mathrm{in.-OD} 304 \mathrm{~L}$ stainless steel pipe with a dished bottom, domed head, and lifting and welding flanges on the head neck. The overall canister length is $9 \mathrm{ft} 10 \mathrm{in}$., with a wall thickness of $3 / 8-\mathrm{in}$. (schedule 20 pipe). The canister length was selected to reduce equipment cell height in the Dh'PF to a practical size. The canister diameter was selected to ensure that a filled canister with its shipping cask could be accommodated on a legal-weight truck. The overall dimensions and weight appear to be generally compatible with preliminary assessments of repository requirements.

The reference waste form is borosilicate glass containing approximately 28 wt \% sludge oxides with the balance glass frit. Borosilicate glass was chosen because of its high resistance to leaching by water, its relatively high solubility for nuclides found in the sludge, and its reasonably low melting temperature. The glass frit contains approximately $58 \% \mathrm{SiO}_{2}$ and $15 \% \mathrm{~B}_{2} \mathrm{O}_{3}$. This composition results in a low average leachability in the waste form of approximately $5 \times 10^{-9} \mathrm{~g} / \mathrm{cm}^{2}$-day based on $137 \mathrm{Cs}$ over 365 days in $25^{\circ} \mathrm{C}$ water. The canister is filled with 3,260 lb of glass which occupies about $85 \%$ of the free canister volume. The filled canister will generate approximately 425 watts when filled with oxides from 5-year-old sludge and 15-year-old supernate from the Stage 1 and Stage 2 processes. The radionuclide content of the canister is about 150,000 curies, with a radiation level of $2 \mathrm{x}$ $10^{4}$ rem/hour at $1 \mathrm{~cm}$. 
CONTENTS

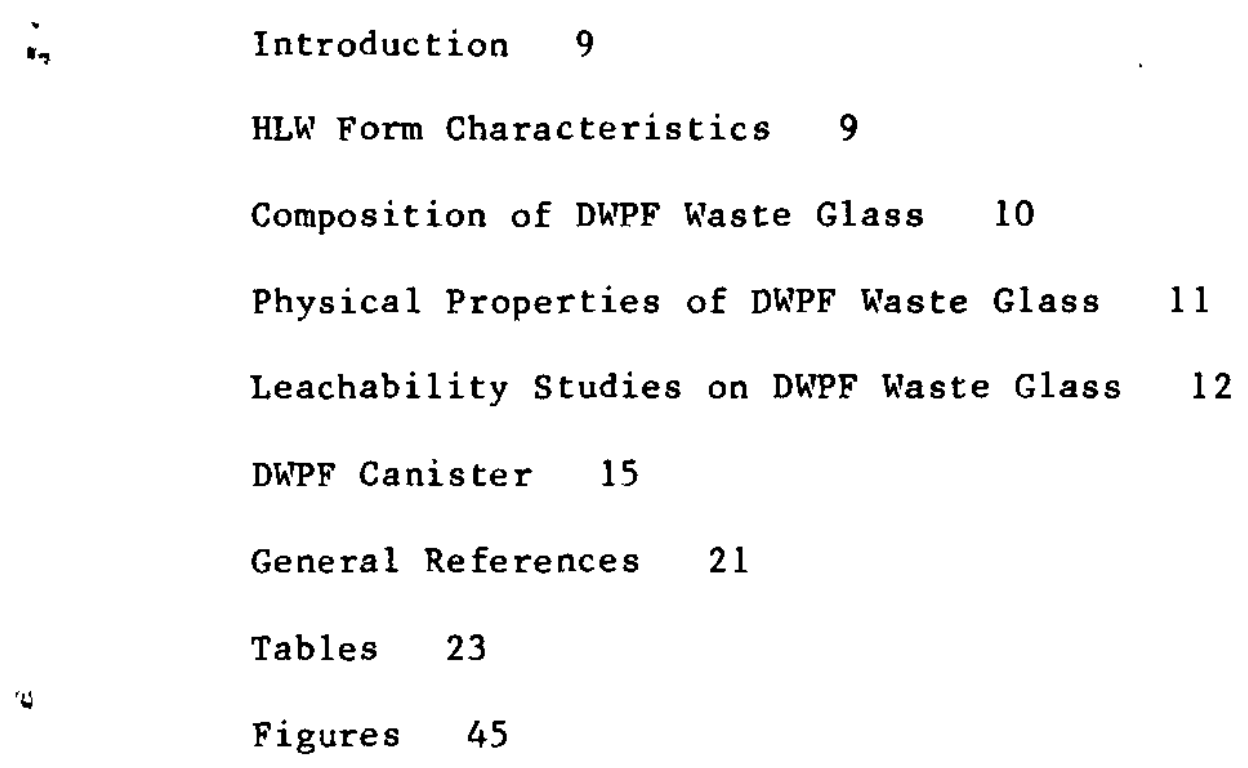

$-5-$ 


\section{LIST OF TABLES}

1 Stage 1 Feed Composition

2 Isotopic Content of Stage 1 Feed

3 Chemical Composition of Glass Frit 131

4 Chemical Composition of Stage 1 Glass Waste Form

5 Isotopic Content of Stage 1 Glass Waste Form

6 Chemical Composition of Stage 2 Feed

7 Isotopic Content of Stage 2 Feed

8 Chemical Composition of Stage 1/Stage 2 Glass Waste Form

9 Isotopic Content of Stage 1/Stage 2 Glass Waste Form

10 Chemical Compositions of Glass Frits

11 Physical Properties of Glass Waste Forms

12 Composition of SRP Simulated Waste Glasses

13 Heat Capacities for SRP Simulated Waste Glasses

14 Densities of SRP Simulated Waste Glasses

15 Index of Refraction for SRP Simulated Waste Glasses

16 Thermal Conductivity of SRP Simulated haste Glasses

17 Principal Metal Ions in Washed, Dried Sludges from SRP Tanks $13 \mathrm{H}$ and $16 \mathrm{H}$

18 Dh'PF Reference Canister Heat Generation

19 Reference Glass Waste Form Surface Temperature

20 Radiation from Reference Canister of Stage 1/Stage 2 Glass

21 Source Terms for Stage 1/Stage 2 Glass 
1 Thermal Expansion Data for 28 Percent Composite Sludge Plus Frit 131

2 Thermal Expansion Data for 20 Percent High-Iron

3 Thermal Expansion Data for 20 Percent High-Aluminum

4 Resistivity of Frit 131/Waste Glasses

5 Published Leach Rates of SRP Glasses

6 Cumulative Leaching of Frit 21-Simulated SRP Sludge Glass in Brine Based on ${ }^{137} \mathrm{Cs}$

7 Cumulative Leaching of Frit 21-SRP Waste Tank No. 13 Glass Based on ${ }^{90} \mathrm{Sr}$

8 Cumulative Leaching of Frit 21-SRP Waste Tank No. 16 Glass Based on ${ }^{90} \mathrm{Sr}$

9 Canister Drawing

10 Two Jaw Grappler Assembly

11 Canister Isotherms at Steady State 


\section{INTRODUCTION}

This document describes the reference glass waste form and the canister planned for the Defense Waste Processing Facility (DWPF). The borosilicate glass waste form and steel canister are the basis for the design and March 1981 budget quality cost estimate for the facility. Waste forms other than borosilicate glass are being studied at SRL and at other sites, however, the glass and canister described in this report is the reference form until a final waste form decision is made by october 1983. At that time, borosilicate glass will be compared to the other alternatives and a selection will be made of the form to be produced in the $D W^{\prime} P F$. In the meantime, the information outlined in this report is suitable for transportation and repository design purposes.

\section{HLW FORM CHARACTERISTICS}

The reference waste form for the DWPF is a borosilicate glass containing approximately 28 wt \% sludge with the balance being glass frit. Borosilicate glass was chosen as a waste form because of its resistance to leaching by water, its relatively high solubility for nuclides found in the sludge, its relatively low melting temperature, and because the process is based upon we 11developed technology.

Description of the waste glass characteristics is divided into three sections: composition, mechanical properties, and leachability. Glass composition is further divided by Stage 1 and Stage 2. Stage 1 is based upon processing just the 5-year-old or older waste sludge. Stage 2 is based upon processing the 5-yearold or older sludge plus a 15-year-old or older supernate fraction containing virtually all of the Cs-137 fraction. Mechanical properties of the waste glass are based upon the current frit candidate, designated as Frit 131.

Data on leachability are based upon an earlier frit composition designated as Frit 21. Current leachability tests in progress are based upon Frit 131 but incorporate testing procedures recommended by the Materials Characterization Committee. These testing procedures supersede those performed with Frit 21 . Final results of the tests will be issued as they 
become available, but results to date indicate that properties of frit 21 and frit 131 glasses are comparable.

\section{COMPOSITION OF DWPF WASTE GLASS}

Feed to the Dh'PF is divided into two stages. Settled, washed sludge is the stage 1 feed for the DWPF. The feed for stage 1 is comprised only of waste tank sludges containing nearly all of the stable and radioactive fission products, actinide elements, and elements added in the separations processes (primarily Fe, Mn, Al, and $\mathrm{Hg}$ ). The sludge is treated with sodium hydroxide to dissolve hydrated aluminum oxides, washed with water to remove soluble salts to 2 wt $\%$ on a dry basis, and then allowed to settle.

In Stage 2, the supernate is processed. The supernate contains the soluble salts, including the Cs-137 fraction. The salt fraction and concentrated supernate are the basis for the Stage 2 feed.

\section{Stage 1}

A description of the chemical composition of stage 1 feed is in Table 1 , and the isotopic content is shown in Table 2. The soluble solids are principally $\mathrm{NaOH}(32 \%), \mathrm{NaNO}_{3}(29 \%), \mathrm{NaAlO}_{2}$ $(16 \%)$, and $\mathrm{NaNO}_{2}(12 \%)$ which constitute about 88 wt \% of the solids in this fraction. Of the insolubles, $\mathrm{Fe}(\mathrm{OH})_{3}(38 \%)$, $\mathrm{Al}(\mathrm{OH})_{3}(16 \%)$, and $\mathrm{MnO}_{2}(6 \%)$ constitute approximately 60 wt \% of the solids in this fraction. Activity of the stage 1 feed is 187 $\mathrm{Ci} / g a 1$ with a decay heat of 0.58 watt/gal for 5 -year aged waste. of this activity, $76 \%$ is due to $\mathrm{Sr}-90, \mathrm{Y}-90$, and $\mathrm{Pm}-147$.

Chemical composition of the current reference frit, designated as Frit 131, is shown in Table 3. The frit is approximately $58 \% \mathrm{SiO}_{2}, 18 \% \mathrm{Na}_{2} \mathrm{O}$, and $15 \% \mathrm{~B}_{2} \mathrm{O}_{3}$. The frit was developed after an extensive series of tests designed to produce a waste glass product with good leach resistance, high solubility for waste oxides, and a practical melting temperature.

Chemical composition of the Stage 1 glass waste form is described in Table 4, and the isotopic content is shown in Table 5. The total activity is $41 \mathrm{Ci} / 1 \mathrm{~b}$, with a decay heat of 0.127 watt/lb for 5-year old waste. Thus, the 3,260-1b canister with Stage 1 waste glass contains about $134,000 \mathrm{Ci}$ with a decay heat of 416 watts. The isotopes of $\mathrm{Sr}-90, \mathrm{y}-90$, and $\mathrm{Pm}-147$ contribute about $76 \%$ to the waste-form activity. 


\section{Stage 2}

A description of the chemical composition of Stage 2 feed is in Table 6, and the isotopic content is shown in Table 7. The soluble solids are principally $\mathrm{NaNO}_{3}(45 \%), \mathrm{NaNO}_{2}(17 \%)$, and $\mathrm{NaAlO}_{2}(10 \%)$ which constitute about 73 wt \% of the solids in this fraction. Of the insolubles, $\mathrm{Al}(\mathrm{OH})_{3}(33 \%)$ and $\mathrm{Fe}(\mathrm{OH})_{3}(30 \%)$ represent approximately 63 wt \% of the solids in this fraction. Activity of the Stage 2 feed is $4.4 \mathrm{Ci} / g a 1$ with a decay heat of 0.01 watt/gal for 15-year-old supernate. Of this activity, $99 \%$ is due to $\mathrm{Cs}-137$ and its beta decay daughter, $\mathrm{Ba}-137 \mathrm{~m}$.

The chemical composition of combined stage 1 sludge and Stage 2 supernate waste glass is shown in Table 8 , and the isotopic content is shown in Table 9. Total activity is $46 \mathrm{Ci} / \mathrm{lb}$ with a decay heat of 0.130 watt/1b for 5-year-old sludge and 15year-old supernate. Thus, the $3,260-1 b$ canister with both stages contains about $150,000 \mathrm{Ci}$ with a decay heat of 423 watts. The isotopes of $\mathrm{Y}-90, \mathrm{Sr}-90, \mathrm{Cs}-137, \mathrm{Ba}-137 \mathrm{~m}$, and $\mathrm{Pm}-147$ contribute about $84 \%$ of the activity.

\section{PHYSICAL PROPERTIES OF DWPF WASTE GLASS}

Physical properties of Dh'PF waste glass have been measured and also estimated by calculation. Most of the properties determined by experiment are based upon Frit 21 rather than the current reference frit, Frit 131 , but no significant differences are expected. The principal differences between the two is that Frit 131 is higher in wt $\%$ of $\mathrm{SiO}_{2}$ and $\mathrm{B}_{2} \mathrm{O}_{3}$, but lower in $\mathrm{TiO}_{2}$ than Frit 21. In addition, $\mathrm{La}_{2} \mathrm{O}_{3}, \mathrm{MgO}$, and $\mathrm{ZrO}_{2}$ were incorporated into Frit 131 to improve glass durability. A detailed comparison with several of the frits evaluated can be made from data in Table 10 .

Physical properties of glass waste forms are listed in Table 11. Of these values, the fractional thermal expansion, the density at $100^{\circ} \mathrm{C}$, and the softening point were experimentally determined for Frit 131 glasses. Other values are based on Frit 21 or other typical glass compositions.

Several physical properties of SRP waste glasses have not been determined experimentally, but can be estimated by calculation. Heat capacity, thermal conductivity, density, and refractive index for three types of DhPF waste glass (composite, high iron, and high aluminum) have been calculated on the basis of glass containing $25.4 \%$ sludge oxides and the balance glass Frit 131. Typical compositions for these three types of glass are shown in Table 12 . 


\section{Heat Capacity}

Heat capacities for DWPF waste glass are listed in Table 13. $\mathrm{Cpm}$ is the mean heat capacity referenced to $0^{\circ} \mathrm{C}$; $\mathrm{Cpt}$ is the true heat capacity at the indicated temperature.

\section{Densities}

Densities for DW'PF waste glass are 1 isted in Table 14. The transition temperature, $\mathrm{Tr} \cong 450^{\circ} \mathrm{C}$, is approximate and differs somewhat for each type of glass.

\section{Thermal Expansion}

Waste glass thermal expansion as a function of temperature is shown in Figure 1 for composite glass, in Figure 2 for high-Fe glass, and in Figure 3 for high-Al glass.

\section{Index of Refraction}

Refractive indices for three types of waste glass are listed in Table 15. The data presented are for a wavelength of $4860 \AA$ and at room temperature. Changes due to temperature are only about $1 \%$ over a range of $1000^{\circ} \mathrm{C}$.

\section{Thermal Conductivity}

Thermal conductivity of a substance is a measure of the heat transferred through a substance by conduction. The effective thermal conductivity is described in Table 16. The change in values around $700^{\circ} \mathrm{C}$ is due to the increasing effect of radiant conductivity.

\section{Electrical Resistivity}

Electrical resistivity of the glass melt as a function of temperature is shown in Figure 4. At the operating melt temperature of $1150^{\circ} \mathrm{C}$, the resistivity is approximately $2.5 \mathrm{ohm}-\mathrm{cm}$.

\section{LEACHABILITY STUDIES ON DWPF WASTE GLASS}

Studies on glass leachability have been in progress at the Savannah River Laboratory for the past seven years as part of a program investigating the properties of glasses containing 
radioactive waste. The borosilicate glass formulations used contain approximately $28 \%$ sludge oxides and are melted with frit compositions of 52 to $58 \% \mathrm{SiO}_{2}$ and 10 to $15 \% \mathrm{~B}_{2} \mathrm{O}_{3}$. These glasses have an initial leach rate of $1 \times 10^{-5} \mathrm{~g} / \mathrm{cm}^{2} / \mathrm{d}$, which drops to about $5 \times 10^{-8} \mathrm{~g} / \mathrm{cm}^{2} / \mathrm{d}$ after 100 days, then to $5 \times 10^{-9} \mathrm{~g} / \mathrm{cm}^{2} / \mathrm{d}$ after 400 days. These nominal values are for temperatures of $25^{\circ} \mathrm{C}$ and $90^{\circ} \mathrm{C}$ in both distilled water and brine and are based upon Cs137 leachability. See Figure 5 which summarizes the band of data for published leach rates of glasses studied at SRL.

Figure 6 describes leach rate data for high-iron, composite, and high-aluminum simulated waste using Frit 21 in brine at $25^{\circ} \mathrm{C}$. The cumulative amount leached is based on $\mathrm{Cs}-137$ and is expressed in $\mathrm{g} / \mathrm{cm}^{2}$. For the $67-$ day test period, the cumulative and average leachabilities are:

$$
\frac{\begin{array}{l}
\text { Cumulative Amount, } \\
\text { g/cnt }
\end{array}}{10 \times 10^{-6}} \frac{\begin{array}{l}
\text { Average Rate, } \\
\mathrm{g} / \mathrm{cm}^{2} / \mathrm{d}
\end{array}}{2 \times 10^{-7}}
$$

High Fe

$$
10 \times 10^{-6}
$$

Composite

$6.5 \times 10^{-6}$

$1 \times 10^{-7}$

High Al

$5 \times 10^{-6}$

$0.7 \times 10^{-7}$

Glass leach rates in $90^{\circ} \mathrm{C}$ brine decreased with time as did rates in $25^{\circ} \mathrm{C}$ brine; however, the leachability at $90^{\circ} \mathrm{C}$ was approximately five times higher than at $25^{\circ} \mathrm{C}$.

Figures 7 and 8 describe leach rate data for actual sludges

\begin{tabular}{|c|c|c|}
\hline Leachant & $\begin{array}{l}\text { Cumulative Amount, } \\
\mathrm{g} / \mathrm{cm}^{2}\end{array}$ & $\begin{array}{l}\text { Average Rate, } \\
\mathrm{g} / \mathrm{cm}^{2} / \mathrm{d}\end{array}$ \\
\hline Water & $2 \times 10^{-5}$ & $1 \times 10^{-7}$ \\
\hline pH 4 Buffer & $2 \times 10^{-3}$ & $1 \times 10^{-5}$ \\
\hline $\mathrm{pH} 7$ Buffer & $6 \times 10^{-5}$ & $3 \times 10^{-7}$ \\
\hline $\mathrm{pH} 9$ Buffer & $8 \times 10^{-5}$ & $4 \times 10^{-7}$ \\
\hline
\end{tabular}
obtained from waste Tanks $13 \mathrm{H}$ and $16 \mathrm{H}$, using Frit 21 glass and solutions at $25^{\circ} \mathrm{C}$ buffered to $\mathrm{pH}$ of 4,7 , and 9 . The cumulative amount leached is based upon $5 r-90$. For the 200-day test period, the cumulative leachabilities based upon Tank $16 \mathrm{H}$ are: 
A listing of the principal metal ions found in Tanks 13 and 16 is shown in Table 17.

Leachability of SRP waste glasses has been studied using three types of tests. Most of the earlier work was done either with Soxhlet tests or those recommended by the International Standards Organization and the International Atomic Energy Agency. Recent work is based upon standardized leaching procedures developed by the Materials Characterization Center.

\section{Glass Cracking}

Since the total amount of material leached is dependent upon the surface area, glass fracture during cooling has been investigated at Battelle-Pacific Northwest Laboratories (PNL) and at SRL. Tests have shown that cracking can be reduced by the use of canister materials that match the glass coefficient of thermal expansion, by the use of canister liners, by slow cooling through the annealing range, and by annealing the solidified form. Based upon data from tests at PNL, the surface area increases by about a factor of 10 when comparing cooling rates of $1^{\circ} \mathrm{C} / \mathrm{hr}$ by annealing with rates of $500^{\circ} \mathrm{C} / \mathrm{hr}$. Thus, if the total glass surface area of the DWPF waste form of $5 \mathrm{~m}^{2}$ is increased by a factor of 10 due to convection cooling, and is combined with an initial leach rate of $5 \times 10^{-6} \mathrm{~g} / \mathrm{cm}^{2} / \mathrm{day}$, then initially about $2 \mathrm{~g}$ of $\mathrm{glass}$ would be leached per day. After a year, however, the leach rate drops by a factor of 1000 , to only $0.002 \mathrm{~g}$ of glass per day.

\section{Repository Temperature}

The most radioactive waste planned for processing in the Dh'PF is aged 5 years, out of reactor. For stage 1 plus stage 2 processing, the heat generated per canister is 423 watts, or 0.677 watt/L of glass. Repository studies indicate that with this low power density the cavity temperatures will be below $100^{\circ} \mathrm{C}$ for a canister spacing of approximately 5 feet. Consequently, glass structural changes due to temperature changes are negligible, and the high temperature $\left(300^{\circ} \mathrm{C}\right)$ hydrothermal reactions will not take place.

\section{Radiation Stability}

During long-term storage, the glass waste form will be continuously irradiated by beta-gamma emissions from fission products and by alpha emissions from transuranic nuclides. The estimated dose during the storage period of $1 \times 10^{6}$ years is 
calculated to be $14 \times 10^{10}$ rads. Results of radiolysis studies indicate that this dose rate has an insignificant effect on the leachability and stored energy of the glass. Larger alpha particle doses increase waste glass leachability by less than a factor of two. SRL tests on waste glasses doped with $244 \mathrm{~cm}$ and ${ }^{238} \mathrm{Pu}$, to simulate an alpha dose in excess of one million years storage ( $\left.4 \times 10^{17} \alpha / g\right)$, indicated only a doubling in leach rate. Similar results were obtained by PNL for dose rates of $10^{20} \alpha / \mathrm{g}$.

After $2 \times 10^{5}$ years of storage, approximately 56 L (STP) of helium will have been produced by radionuclide decay in $625 \mathrm{~L}$ of waste glass. Assuming helium diffuses through the glass into the 103-L freeboard above the surface, the gas pressure will increase by about $8 \mathrm{psi}$.

Measurements of thermal expansion indicate a growth of less than $1 \%$ due to alpha irradiation over a similar time period.

\section{Groundwater $\mathbf{p H}$}

The effect of leachant $\mathrm{pH}$ on the rate of borosilicate glass dissolution was measured at SRL at room temperature and $90^{\circ} \mathrm{C}$. The studies indicate an optimum $\mathrm{pH}$ of 6 to 8.5. Above $\mathrm{pH} 9$ and below $\mathrm{pH} 5$, glass corrosion increases. Most groundwaters from the proposed repositories of brine, basalt, tuff, shale, and granite fall between a pH of 5 to 9 .

\section{DWPF CANISTER}

\section{Lifting Fixture Dimensions}

The lifting fixture is specific for the DWPF canister and is described in the attached drawing 4712900 , Revision 0 , "2 Jaw Grappler Assembly." The fixture operates by using an air motor to drive two opposed jaws which fit under the lower of the two canister neck flanges. In the event of air motor failure, a mechanical connector driven by a crane impact wrench is provided as a backup. The upper canister flange is used to provide an electrical grounding surface for the upset resistance weld process. In the future, the neck design may be simplified by combining the lifting and grounding flanges, thereby shortening the neck.

\section{Canister Dimensions}

Canister dimensions and weight are shown on the attached drawing D179292, Revision 16, "Canister." 
Principal dimensions and tolerances are:

$\begin{array}{ll}\text { Overall Length } & 9 \mathrm{ft} 10.0 \mathrm{in} . \pm 0.25 \mathrm{in} . \\ \text { Outside Diameter } & 24.00 \mathrm{in} .+0.35 \mathrm{in} . \\ \text { Wall Thickness } & 0.375 \mathrm{in} . \text { nominal pipe tolerance } \\ \text { Bow } & 1 / 4 \mathrm{in.} \mathrm{max.} \\ \text { Surface Finish } & 125 \mathrm{rms} \\ \text { Inside Volume } & 25.7 \mathrm{ft}^{3} \text { nominal } \\ \text { Weight, empty } & 10001 \mathrm{~b} \pm 5 \% \\ \text { Weight, full } & 42601 \mathrm{~b} \pm 5 \% \\ \text { Material } & 304 \mathrm{~L} \mathrm{stainless} \mathrm{steel}\end{array}$

\section{Material of Construction}

Type 304L stainless steel was chosen as the canister material for vitrified waste using the continuous melter process. This recommendation is based on long-term heating tests for up to 20,000 hours $(2.3 \mathrm{yr})$ at temperatures that bracket those expected during interim storage. In these tests, the lifetime of canisters containing vitrified waste glass stored in air was predicted. The thickness of reaction layer observed between the canister alloy and the canister alloy-environment, similar to that expected during interim storage, was extrapolated to estimate the time required for penetration of the 3/8-in.-thick canister.

Data from tests up to 20,000 hours indicate that a $3 / 8-i n .-$ thick canister of Type 304L stainless steel would not be penetrated for more than 8000 years in a surface facility. By contrast, a 3/8-in.-thick low carbon steel canister would be penetrated by oxidation in about 200 years of storage in a surface facility, and its strength would be reduced in a much shorter period.

Differences in canister lifetime, predicted from the data from these tests, are attributable to the differences in corrosion resistance of the candidate alloys. Both Type 304L stainless steel and low carbon steel react similarly with vitrified waste, but Type 304L stainless steel is much more resistant to atmospheric corrosion in a radiation field than is low carbon steel. The lifetime of canisters constructed from other compositions of austenitic stainless steels would be expected to be similar to Type 304L.

Stainless steel has the additional advantage of a relatively low spallation rate when used in the backup in-can melting process. Tests made at PNL indicate that an inert gas blanket 
would have to be used with a carbon steel canister to reduce the oxide scale formation to less than $22 \mathrm{lb}$ per canister. Furthermore, the stainless steel surface is easier to decontaminate by blasting with a frit-water slurry than is carbon steel.

The 0.375-in. nominal wall thickness of a schedule 20, 24-in. stainless steel pipe is adequate for DWPF processing. A theoretical stress analysis was made on the reference canister just after filling with glass at the instantaneous pour rate of $3.8 \mathrm{lb} / \mathrm{min}$. A maximum wall temperature of $427^{\circ} \mathrm{C}$ and a maximum bottom head temperature of $649^{\circ} \mathrm{C}$ was assumed. The calculations show that the wall thickness is sufficient to pick up the canister immediately after filling, despite the residual shell hoop stress of 32,500 psi caused by the lower coefficient thermal expansion of glass compared to stainless steel. Similarly, the thermal axial stresses were calculated to be $18,900 \mathrm{psi}$, and the simple static stresses due to weight were $477 \mathrm{psi}$ shear and $177 \mathrm{psi}$ axial. None of these stress levels indicates the need for a wall thickness greater than $3 / 8$ in.

The canister should not be less than 24-in. diam, but could be larger. Cost analyses on the DWPF of various canister geometries are being developed to update an earlier study which indicated that a penalty of $\$ 225 \mathrm{million}$ (expressed in 1984 dollars) would be incurred over the campaign life for processing $S R$ waste, if the canister diameter were reduced from 24 to 18 in. The study included the cost impact on canisters, processing building, interim storage building, shipping facilities, and shipping casks. The updated studies of the effect of canister diameter on the DWPF facility are expected to be completed by June 1981, and the transportation section by July 1981. The companion studies for repository costs are being done by the Office of Waste Isolation and are scheduled for completion by December 1981 .

\section{Canister Weight}

The canister is filled with approximately 165 gal of glass $\left(22.1 \mathrm{ft}^{3}\right)$ to a fill height of $7 \mathrm{ft} 7 \mathrm{in}$. This volume corresponds to a weight of $3260 \mathrm{lb}$ for the current frit and waste loading, and is about $86 \%$ of the available canister volume. The fill volume was chosen based upon operating experience at PNL where about a $15 \%$ void is made available in the event of: low density foam partially filling the canister; "roping" of the glass stream, causing voids in the frozen melt; and the possibility of spilling glass on the process room floor due to malfunction of load cells, failure of pouring equipment, operator error, etc. After DWPF operating experience is gained, it may be possible to fill the 
canister to a higher level. Maximum weight of the glass form when the canister is filled to $100 \%$ capacity is $38001 \mathrm{~b}$; estimated weight of the empty stainless steel canister shell is approximately $1000 \mathrm{lb}$.

\section{Internal Pressurization Potential}

Internal pressure within the canister is due to accumulation of helium from alpha emissions of transuranic nuclides. A DWPF canister filled with waste glass produces about $0.32 \mathrm{~cm}^{3}$ of helium per year at $40^{\circ} \mathrm{C}$. The helium produced is assumed to diffuse through the glass into the void space above the solid glass surface. At the end of 1000 years, the $3.64 \mathrm{ft}^{3}$ void space pressure has increased by only $0.05 \mathrm{psi}$. This negligible pressure buildup is of no concern in waste package design.

\section{Seal Weld}

The reference process for sealing the canister is to upset resistance weld a $5-i n .-d i a, 1 / 2-i n .-t h i c k, 304 \mathrm{~L}$ stainless steel plug into the canister neck. A force of $75,0001 \mathrm{~b}$, a current of 230,000 amps, and a voltage of approximately 11 volts is used to make the $2-\mathrm{sec}$ weld. The technique was chosen after consideration of seven alternative processes including gas tungsten arc, gas metal arc, plasma arc, Thermit, electron beam, laser beam, and friction welding. Weld tensile strength measurements were made on the upset resistance weld under varying conditions of oxidation to determine the need for machining the throat surface after filling the canister with glass. An upset resistance weld with a 5-in.-dia plug and a machined canister neck was leak-tight to approximately $10^{-8} \mathrm{~atm}-\mathrm{cm}^{3} / \mathrm{sec}$ for a hydrostatic test pressure of 5,000 psig. If the canister neck is heated to $600^{\circ} \mathrm{C}$, but not machined prior to welding, then the weld strength as measured by tensile and hydrostatic tests was reduced by about $20 \%$. However, temperature measurements made on the canister neck during glass filling indicate that the maximum neck temperature does not exceed $300^{\circ} \mathrm{C}$, so the canister seal weld is capable of withstanding at least 4,000 psi internal pressure while still maintaining a leak specification of $1 \times 10^{-8} \mathrm{~atm}-\mathrm{cm}^{3} / \mathrm{sec}$. Leak testing of the plug weld may be required before the canister is placed into a repository. To accomplish this, the plug would have a heliumfilled capsule attached to the bottom face of the plug, projecting into the canister void space. The capsule will have a low melting alloy disc which when heated will release helium gas within the canister. The weld can then be checked with a standard helium leak detector. 
In the event the canister is used in a repository with a flexible overpack and an open-ended sleeve, the canister could be subjected to relatively high lithostatic or hydrostatic pressures. Burial in a salt repository at $600 \mathrm{~m}$ is equivalent to a hydrostatic pressure of $850 \mathrm{psi}$, which would buckle the $3 / 8-i n$. canister dome above the glass melt surface. To prevent buckling, the dome head could have supporting ribs welded to the head interior. Modification to the canister head, if required, will be accomplished when repository criteria are determined.

\section{Fissionable Material and Heat Flux}

The radionuclide content and decay heat generation for glasses containing sludge and supernate are listed below. The ages were chosen to illustrate decay heat variation with waste age.

\begin{tabular}{|c|c|c|c|c|c|}
\hline Stage & haste Conter & & & $\begin{array}{l}\text { Watts per } \\
\text { Canister }\end{array}$ & Curies \\
\hline $\begin{array}{l}1 \\
2\end{array}$ & $\begin{array}{l}5-y r \text { Sludge } \\
5 \text {-yr Sludge }\end{array}$ & Plus $15-y r$ & Supernate & $\begin{array}{l}416 \\
423\end{array}$ & $\begin{array}{l}1.34 \times 10^{5} \\
1.50 \times 10^{5}\end{array}$ \\
\hline $\begin{array}{l}1 \\
2\end{array}$ & $\begin{array}{l}15 \text {-yr Sludge } \\
15 \text {-yr Sludge }\end{array}$ & Plus $15-y r$ & Supernate & $\begin{array}{l}224 \\
256\end{array}$ & $\begin{array}{l}\sim 0.7 \times 10^{5} \\
\sim 0.8 \times 10^{5}\end{array}$ \\
\hline
\end{tabular}

Radioactive decay heat as a function of waste age is shown in Table 18 for Stage 1 and Stage 1 plus 2 waste glass. In 50 years, the canister power has dropped to approximately 110 watts; by 1000 years, the power is only approximately 0.7 watt.

Surface temperatures of a bare glass form containing 5-yr-old waste with DWPF dimensions of 23-1/4 in. dia, 91 in. height, and power levels of 500 and 1000 watts are shown in Table 19. A typical temperature distribution for a 1000-watt canister and overpack, is shown in Figure 11 .

\section{Surface Radiation Dose and Gamma Spectrum}

Surface radiation dose as a function of distance for a reference canister is shown in Table 20. The calculations are based upon the photon energy distribution for 5-year-old waste shown in Table 21 . The radiation dose $1 \mathrm{~cm}$ from the surface is calculated to be $2.5 \times 10^{4}$ rems $/ \mathrm{hr}$. 


\section{Canister Surface Contamination}

The criteria selected for canister surface contamination levels are identical to those specified for Department of Transportation shipping limits and are useful guides for canister decontamination by the frit-water slurry blasting technique. Canisters decontaminated to these levels are not expected to significantly contribute to air contamination within the Interim Storage Building. The canister surface contamination limits selected are:
Alpha
$220 \mathrm{dis} / \mathrm{min} / 100 \mathrm{~cm}^{2}$
Bet a-Gamma
$2200 \mathrm{dis} / \mathrm{min} / 100 \mathrm{~cm}^{2}$

\section{Labeling}

Each canister will have a number stamped on the horizontal and vertical faces of the upper flange. The numbers will be approximately l-in. high and will be visible by television viewing. Each number will identify the canister fabrication and processing history. 


\section{GENERAL REFERENCES}

N. E. Bibler and J. A. Kelley. Effect of Internal Alpha Radiation on Borosilicate Glass Containing Savannah River Plant Wastes. USDOE Report DP-1482. E. I. du Pont de Nemours \& Co., Savannah River Labotatory, Aiken, SC (1978).

G. J. McCarthy, S. Komareni, B. E. Sheetz, and W. B. White. "Hydrothermal Reactivity of Simulated Waste Forms and WaterCatalyzed Waste-Rock Interactions." Science Underlying Radioactive Waste Management. Plenum Press, New York, NY (1978).

M. J. Plodinec. "Improved Glass Compositions for Immobilization of SRP Waste." Scientific Basis for Nuclear Waste Management Vol. 2. Plenum Press, New York, NY, p 223 (1980).

W. S. Ross. "Thermal Fracture Behavior of Glass in Simulated Glass Canisters." Quarterly Research Report, Research and Development Activities, Waste Fixation Program. USERDA Report BNWL-1893, Battelle-Pacific Northwest Laboratory, Rich1and, WA $(1975)$.

K. Scheffler and. J. Riege. Investigations on the Long-Term Radiation of Borosilicate Glass Containing Savannah River Plant Wastes. USDOE Report DP-1428, E. I. du Pont de Nemours \& Co., Savannah River Laboratory, Aiken, SC (1978).

J. A. Stone. Separation of SRP Waste Sludge and Supernate. USDOE Report DP-1441, E. I. du Pont de Nemours \& Co., Savannah River Laboratory, Aiken, SC (1976).

D. D. Walker, J. R. Wiley, M. D. Dukes, and J. H. LeRoy. "Leach Rate Studies on Glass Containing Actual Radioactive Waste." ORNL Conference on Leachability. Proceedings, Gatlinburg, TN $(1980)$.

G. G. Wicks "Borosilicate Glass as a Matrix for Immobilization of SRP High-Level Waste." American Nuclear Society Topical Meeting Waste Management ' 81 . Proceedings, Tucson, AR (1981).

J. R. Wiley. "Leach Rates of High Activity Waste from Borosilicate Glass." Nuc1. Tech. 43, 268 (1979). 
TABLES 
TABLE 1

\section{Stage 1 Feed Composition*}

Soluble Solids

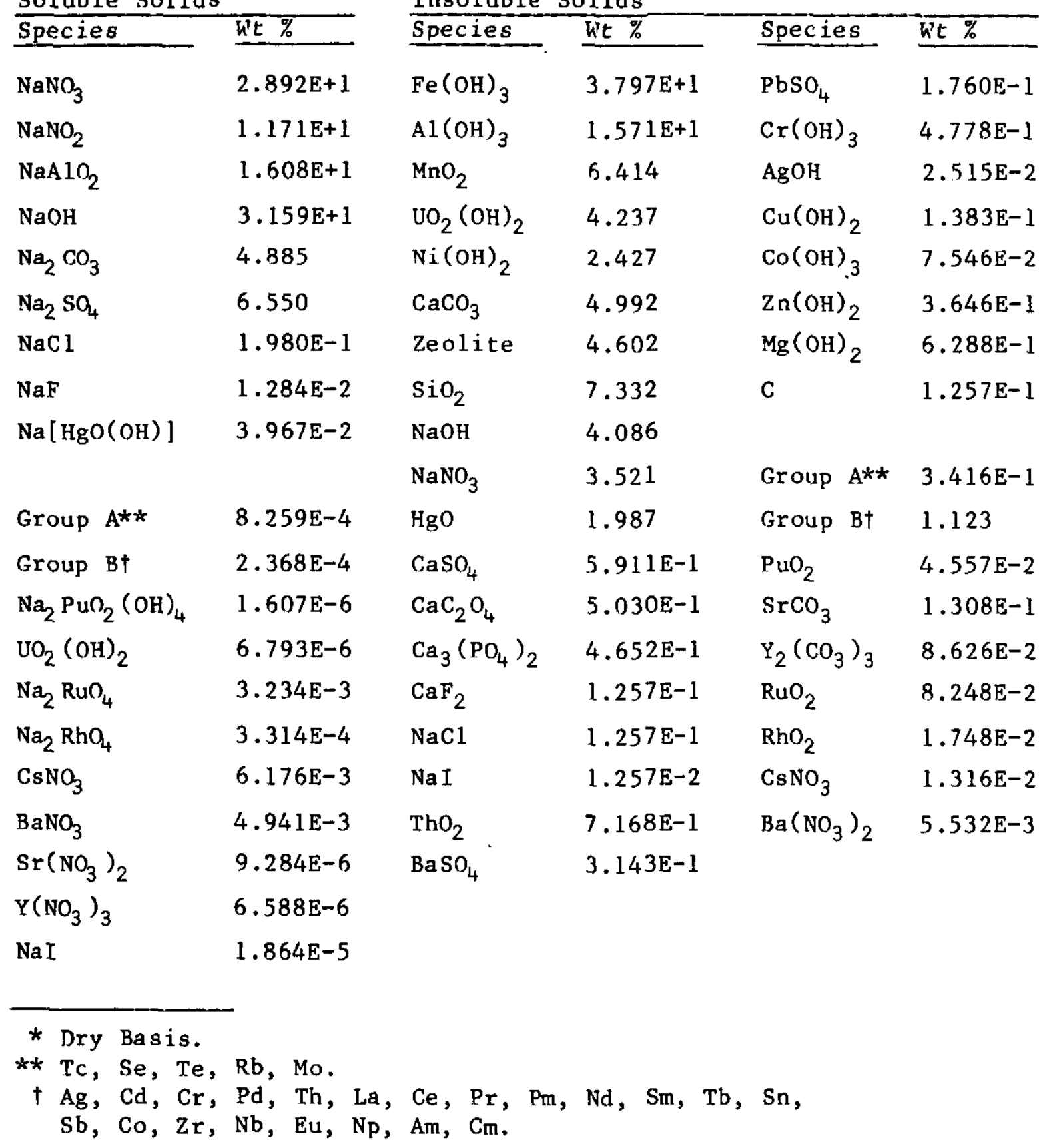

Insoluble Solids

4.086

.521

$.911 \mathrm{E}-1 \quad \mathrm{PuO}_{2}$

$4.557 \mathrm{E}-2$

$1.308 \mathrm{E}-1$

$8.248 \mathrm{E}-2$

$.748 \mathrm{E}-2$ 3 


\section{TABLE 2}

Isotopic Content of Stage 1 Feed - Ci/gal (FS-1-1)

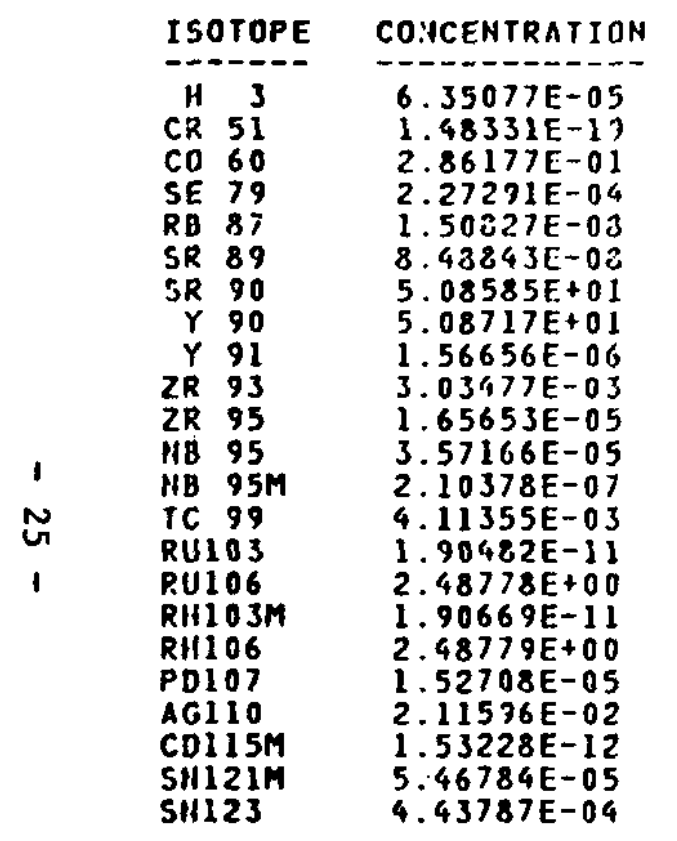

\begin{tabular}{|c|c|}
\hline I SOTOPE & CONCENTRATION \\
\hline 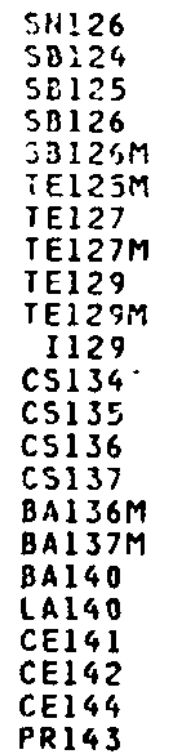 & $\begin{array}{l}2.52141 \mathrm{E}-05 \\
1.19509 \mathrm{E}-10 \\
1.41250 \mathrm{E}+00 \\
3.52997 \mathrm{E}-06 \\
2.52141 \mathrm{E}-05 \\
3.31008 \mathrm{E}-01 \\
1.44495 \mathrm{E}-04 \\
1.47519 \mathrm{E}-04 \\
3.65090 \mathrm{E}-15 \\
5.75014 \mathrm{E}-15 \\
1.33014 \mathrm{E}-05 \\
3.20104 \mathrm{E}-03 \\
5.52726 \mathrm{E}-08 \\
9.4444 \mathrm{E}-45 \\
2.95309 \mathrm{E}-02 \\
3.02223 \mathrm{E}-45 \\
2.79362 \mathrm{E}-02 \\
3.50468 \mathrm{E}-43 \\
7.22159 \mathrm{E}-40 \\
5.99319 \mathrm{E}-14 \\
1.59243 \mathrm{E}-08 \\
1.64616 \mathrm{E}+01 \\
1.99844 \mathrm{E}-37\end{array}$ \\
\hline
\end{tabular}

TOTAL ACTIVITY DECAY HEAT

TOTAL PRIMARY TOTAL GAMMA

\begin{tabular}{lc} 
ISOTOPE & CONCENTRATION \\
\hline PR144 & $1.64622 E+01$ \\
PR144M & $1.97543 E-01$ \\
ND144 & $8.02685 E-13$ \\
ND147 & $2.11823 E-47$ \\
PM147 & $4.03393 E+01$ \\
PMI48 & $1.16056 E-13$ \\
PM148M & $1.68276 E-12$ \\
SM147 & $3.18789 E-09$ \\
SM148 & $9.38640 E-15$ \\
SM149 & $2.90951 E-15$ \\
SM151 & $3.93519 E-01$ \\
EU152 & $6.34768 E-03$ \\
EU154 & $1.04271 E+00$ \\
EU155 & $8.25415 E-01$ \\
EU156 & $8.80026 E-35$ \\
IB160 & $1.86795 E-09$ \\
TL206 & $7.58394 E-21$ \\
TL207 & $1.12570 E-10$ \\
TL208 & $1.75650 E-06$ \\
TL209 & $7.15550 E-15$ \\
U232 & $8.55505 E-06$ \\
U233 & $1.01380 E-09$ \\
U234 & $2.67192 E-05$
\end{tabular}
U235 U236 $U 236$
U238 HIP 236 HPP 236

PU236

PU237

PU233

PU230

PU239

PU240

PU241

PU242

Alt2. 41

AM242

AM242M

A.11243

CiI242

CM243

CI1244

CM245

CM246

CM248

\section{$1.87 \mathrm{E}+02 \mathrm{C1} / \mathrm{gal}$}

$5.54 \mathrm{E}-01$ watt/gal 2. 50E-02 watt/ga1 
TABLE 3

Chemical Composition of Glass Frit 131

Oxide $\quad \underline{\text { Wt } \%}$

$\mathrm{SiO}_{2} \quad 57.9$

$\begin{array}{ll}\mathrm{Na}_{2} \mathrm{O} & 17.7\end{array}$

$\mathrm{B}_{2} \mathrm{O}_{3} \quad 14.7$

$\mathrm{Li}_{2} \mathrm{O} \quad 5.7$

MgO 2.0

$\mathrm{TiO}_{2} \quad 1.0$

$\mathrm{ZrO}_{2} \quad 0.5$

$\mathrm{La}_{2} \mathrm{O}_{3} \quad 0.5$ 


\section{TABLE 4}

\section{Chemical Composition of Stage 1 Glass Waste Form}

\begin{tabular}{|c|c|}
\hline Compound & Wt $\%$ \\
\hline $\mathrm{SiO}_{2}$ & 45.5 \\
\hline $\mathrm{Na}_{2} \mathrm{O}$ & 15.0 \\
\hline $\mathrm{B}_{2} \mathrm{O}_{3}$ & 10.9 \\
\hline $\mathrm{Fe}_{2} \mathrm{O}_{3}$ & 6.57 \\
\hline $\mathrm{Li}_{2} \mathrm{O}$ & 4.23 \\
\hline $\mathrm{Al}_{2} \mathrm{O}_{3}$ & 3.62 \\
\hline $\mathrm{Fe}_{3} \mathrm{O}_{4}$ & 3.13 \\
\hline $\mathrm{MnO}$ & 1.81 \\
\hline $\mathrm{MgO}$ & 1.64 \\
\hline Zeolite & 1.59 \\
\hline $\mathrm{UO}_{2}$ & 1.30 \\
\hline $\mathrm{CaO}$ & 1.16 \\
\hline $\mathrm{TiO}_{2}$ & 0.743 \\
\hline $\mathrm{NiO}$ & 0.677 \\
\hline$B^{*}$ & 0.389 \\
\hline $\mathrm{La}_{2} \mathrm{O}_{3}$ & 0.371 \\
\hline $\mathrm{ZrO}_{2}$ & 0.371 \\
\hline $\mathrm{ThO}_{2}$ & 0.248 \\
\hline $\mathrm{Ca}_{3}\left(P \mathrm{q}_{4}\right)_{2}$ & 0.161 \\
\hline $\mathrm{Cr}_{2} \mathrm{O}_{3}$ & 0.122 \\
\hline$A^{* *}$ & 0.112 \\
\hline $\mathrm{ZnO}$ & 0.103 \\
\hline $\mathrm{BaO}$ & .0696 \\
\hline $\mathrm{Pbo}$ & .0448 \\
\hline $\mathrm{Cu}_{2} \mathrm{O}$ & 0.0351 \\
\hline Sro & .0318 \\
\hline $\mathrm{RuO}_{2}$ & .0257 \\
\hline $\mathrm{Y}_{2} \mathrm{O}_{3}$ & 0.0188 \\
\hline $\mathrm{COO}$ & 0.0178 \\
\hline $\mathrm{PuO}_{2}$ & 0.0158 \\
\hline $\mathrm{RhO}_{2}$ & 0.00544 \\
\hline $\mathrm{Cs}_{2} \mathrm{O}$ & 0.00316 \\
\hline Total & 100.00 \\
\hline
\end{tabular}

\footnotetext{
* $\mathrm{B}=\mathrm{Ag}, \mathrm{Cd}, \mathrm{Cr}, \mathrm{Pd}, \mathrm{T} 1, \mathrm{La}, \mathrm{Ce}, \mathrm{Pr}, \mathrm{Pm}, \mathrm{Nd}, \mathrm{Sm}$, $\mathrm{Tb}, \mathrm{Sn}, \mathrm{Sb}, \mathrm{Co}, \mathrm{Zr}, \mathrm{Nb}, \mathrm{Eu}, \mathrm{Np}, \mathrm{Am}, \mathrm{Cm}$.

** $\mathrm{A}=\mathrm{Tc}, \mathrm{Se}, \mathrm{Te}, \mathrm{Rb}, \mathrm{Mo}$ - $27-$
} 
TABLE 5

Isotopic Content of Stage 1 Glass Waste Form - Ci/1b (FS-2-1)

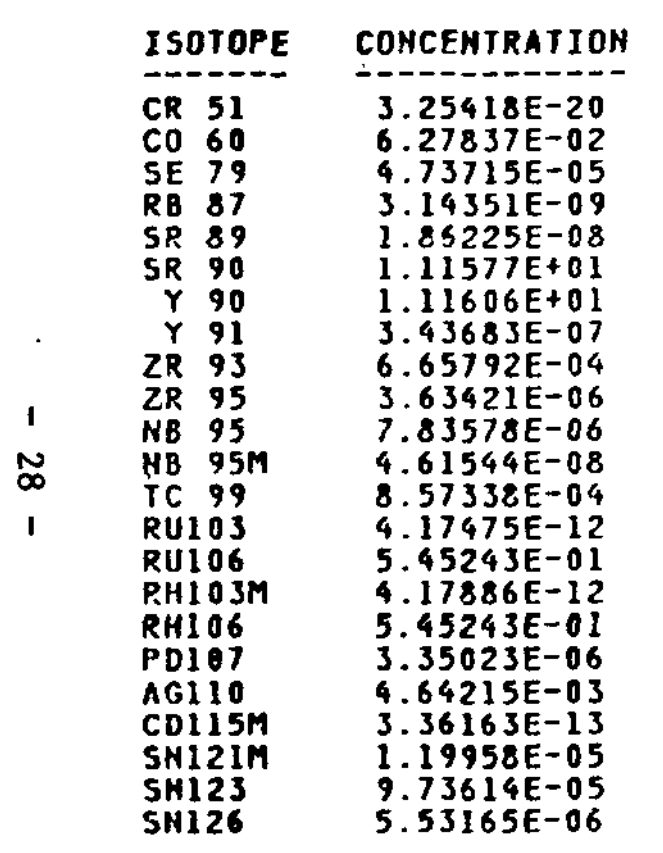

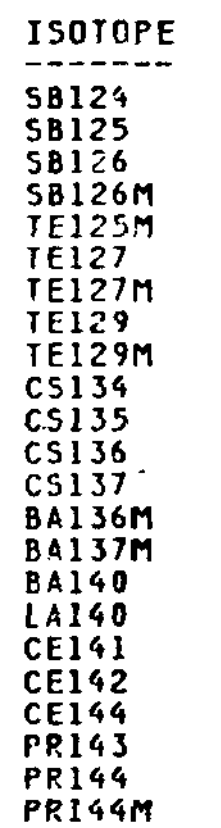

CONCENTRATION
$-2.62187 E-11$
$3.09884 E-01$
$7.74431 E-07$
$5.53166 E-06$
$6.89830 E-02$
$3.01153 E-05$
$3.07456 E-05$
$7.60915 E-16$
$1.19843 E-15$
$7.01898 E-04$
$1.21197 E-08$
$2.07091 E-45$
$6.47529 E-03$
$6.62690 E-46$
$6.12562 E-03$
$7.68479 E-44$
$1.58433 E-40$
$1.31483 E-14$
$3.49359 E-09$
$3.61146 E+00$
$4.38433 E-38$
$3.61159 E+00$
$4.33383 E-02$

\begin{tabular}{l} 
ISOTOPE \\
\hline ND144 \\
ND147 \\
PMI 47 \\
PM1 148 \\
PMI $48 M$ \\
SM147 \\
SM148 \\
SM149 \\
SM151 \\
EU152 \\
EU154 \\
EU155 \\
EU156 \\
TB160 \\
TL206 \\
TL207 \\
TL208 \\
TL209 \\
U232 \\
U233 \\
U234 \\
U235
\end{tabular}

\begin{tabular}{l} 
CONCENIRATION \\
\hdashline $1.76099 E-13$ \\
$4.64714 \mathrm{E}-48$ \\
$8.84994 \mathrm{E}+00$ \\
$2.54612 \mathrm{E}-14$ \\
$3.69177 \mathrm{E}-13$ \\
$6.99383 \mathrm{E}-10$ \\
$2.05926 \mathrm{E}-15$ \\
$6.38310 \mathrm{E}-16$ \\
$8.63330 \mathrm{E}-02$ \\
$1.39260 \mathrm{E}-03$ \\
$2.28757 \mathrm{E}-01$ \\
$1.81086 \mathrm{E}-01$ \\
$1.93067 \mathrm{E}-35$ \\
$4.09806 \mathrm{E}-10$ \\
$1.66382 \mathrm{E}-21$ \\
$2.46964 \mathrm{E}-11$ \\
$3.85353 \mathrm{E}-07$ \\
$1.56983 \mathrm{E}-15$ \\
$1.87687 \mathrm{E}-06$ \\
$2.22416 \mathrm{E}-10$ \\
$5.86186 \mathrm{E}-06$ \\
$1.93628 \mathrm{E}-08$
\end{tabular}

ISOTOPE

4236

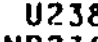

NP2 36

NP2 237

PU236

PU237

PU238

PU239

PU240

PU241

PU242

AM241

AM242

AM242M

AM243

C11242

CI1243

Cl1243
CM244

C11245

CM246

CM247

CM248
CONCFHTRATIOH

4. $19969 \mathrm{E}-07$

$1.06556 E-07$

6. $35349 \mathrm{E}-12$

$3.230815-06$

2. $29285 E-05$

1. $67329 \mathrm{E}-15$

2.75432E-01

2. $59239 E-03$

1. $63824 \mathrm{E}-03$

$1.63824 E-03$

.

2. $18282 \mathrm{E}-06$

$3.96470 E-03$

5. $23261 E-06$

5. $25885 \mathrm{E}-0 \mathrm{G}$

$2.11334 \mathrm{E}-06$

1. $28441 \mathrm{E}-05$

$441 \mathrm{E}-05$

2.03561E-06

$5.96933 E-05$

2. $43538 E-09$

$1.94395 \mathrm{E}-10$

2.38971E-16

$2.49552 \mathrm{E}-16$
TOTAL ACTIVITY DECAY HRAT

TOTAL PRIMARY TOTAL GAMMA
4.11E+01 Cl/1b

1. 22E-01 watt/1b

$5.49 \mathrm{E}-03$ watt $/ 1 \mathrm{~b}$ 
TABLE 6

Chemical Composition of Stage 2 DWPF Feed

$\underline{\text { lb/gal }}$

Soluble Solids -3.11

Insoluble Solids - 9.75E-5

Water

$-7.26$

Soluble Solids, wt \% Insoluble Solids, wt \%

\begin{tabular}{|c|c|c|c|}
\hline $\mathrm{NaNO}_{3}$ & 44.89 & $\mathrm{Al}(\mathrm{OH})_{3}$ & 32.96 \\
\hline $\mathrm{NaNO}_{2}$ & 17.29 & $\mathrm{Fe}(\mathrm{OH})_{3}$ & 30.20 \\
\hline $\mathrm{NaAlO}_{2}$ & 10.33 & $\mathrm{SiO}_{2}$ & 5.83 \\
\hline $\mathrm{NaOH}$ & 9.71 & $\mathrm{MnO}_{2}$ & 5.10 \\
\hline $\mathrm{Na}_{2} \mathrm{SO}_{4}$ & 9.70 & $\mathrm{CaCO}_{3}$ & 3.97 \\
\hline $\mathrm{Na}_{2} \mathrm{CO}_{3}$ & 7.24 & Zeolite & 3.66 \\
\hline $\mathrm{NaCl}$ & 0.293 & $\mathrm{UO}_{2}(\mathrm{OH})_{2}$ & 3.37 \\
\hline $\mathrm{NaF}$ & 0.0191 & $\mathrm{NaOH}$ & 3.25 \\
\hline $\mathrm{Na}(\mathrm{HgO}(\mathrm{OH}))$ & 0.0584 & $\mathrm{NaNO}_{3}$ & $2.80 *$ \\
\hline \multirow[t]{12}{*}{$\mathrm{Na}_{2} \mathrm{C}_{2} \mathrm{O}_{4}$} & 0.473 & $\mathrm{Ni}(\mathrm{OH})_{2}$ & 1.93 \\
\hline & & $\mathrm{HgO}$ & 1.58 \\
\hline & & $\mathrm{CaSO}_{4}$ & 0.47 \\
\hline & & $\mathrm{CaC}_{2} \mathrm{O}_{4}$ & 0.40 \\
\hline & & $\mathrm{Ca}_{3}\left(\mathrm{PO}_{4}\right)_{2}$ & 0.37 \\
\hline & & $\mathrm{BaSO}_{4}$ & 0.25 \\
\hline & & $\mathrm{PbSO}_{4}$ & 0.14 \\
\hline & & $\mathrm{CaF}_{2}$ & 0.10 \\
\hline & & $\mathrm{NaCl}$ & $0.10 *$ \\
\hline & & $\mathrm{C}$ & 0.10 \\
\hline & & $\mathrm{NaI}$ & 0.01 \\
\hline & & Others & 3.41 \\
\hline
\end{tabular}

* Insoluble fraction of normally soluble salt. 
TABLE 7

Isotopic Content of Stage 2 Feed - Ci/gal (FS-4-1)

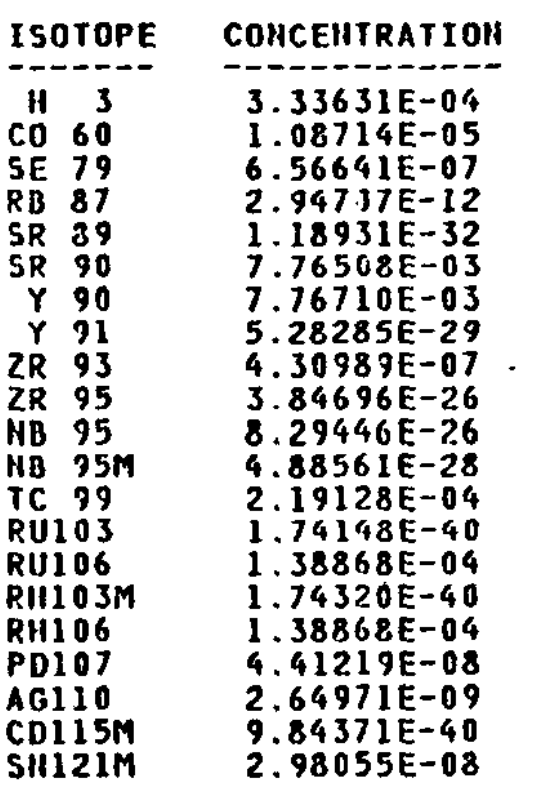

\begin{tabular}{ll} 
ISOTOPE & CONCENTRATION \\
\hline SN123 & $8.33427 E-16$ \\
SN126 & $1.57895 \mathrm{E}-08$ \\
SB124 & $4.07284 \mathrm{E}-32$ \\
SB125 & $6.98298 \mathrm{E}-05$ \\
SB126 & $2.21053 \mathrm{E}-09$ \\
SB126M & $1.57895 \mathrm{E}-08$ \\
TE125M & $7.55018 \mathrm{E}-05$ \\
TE127 & $3.41502 \mathrm{E}-17$ \\
IE127M & $3.48648 \mathrm{E}-17$ \\
TE129. & $1.26969 \mathrm{E}-50$ \\
TE123M & $1.99975 \mathrm{E}-50$ \\
I129 & $3.84318 \mathrm{E}-08$ \\
CS134 & $1.06496 \mathrm{E}-02$ \\
CS135 & $5.31933 \mathrm{E}-06$ \\
CS137 & $2.25744 \mathrm{E}+00$ \\
BA137M & $2.13553 \mathrm{E}+00$ \\
CE141 & $5.94908 \mathrm{E}-51$ \\
CE142 & $9.97212 \mathrm{E}-12$ \\
CE144 & $1.40323 \mathrm{E}-06$ \\
PR144 & $1.40329 \mathrm{E}-06$ \\
PR144M & $1.68391 \mathrm{E}-08$
\end{tabular}

Total Activity Decay Heat

Total Primary

Total Gammas

ISOTOP
ND144
PM147
PMI 148
PMI $18 M$
SM147
SM148
SM149
SM151
EU152
EU154
EU155
IB160
TL206
TL207
TL208
TL209
U232
U233
U234
U235
U236

\section{CONCENTRATION}

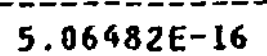

$5.06482 E-16$

$1.73319 \mathrm{E}-43$

$2.51306 E-42$

$2.57189 \mathrm{E}-12$

$5.87796 \mathrm{E}-18$

$1.82200 \mathrm{E}-18$

$2.28719 E-04$

$5.28736 \mathrm{E}-07$

$6.61044 E-05$

$2.76330 E-05$

$7.25143 E-28$

$7.32144 \mathrm{E}-22$

$8.94281 \mathrm{E}-13$

$1.08530 \mathrm{E}-08$

$9.41467 \mathrm{E}-17$

$1.60696 \mathrm{E}-09$

2. $35222 \mathrm{E}-13$

$8.65191 E-09$

$1.25342 \mathrm{E}-11$

$2.72175 \mathrm{E}-10$

4.42E+00 $\mathrm{Ci} / \mathrm{gal}$

2.40E-03 watt/gal

$7.64 \mathrm{E}-03$ watt/gal

\begin{tabular}{l} 
ISOTOPE \\
\hline$U 238$ \\
HP236 \\
IP 237 \\
PU236 \\
PU237 \\
PU238 \\
PU239 \\
PU240 \\
PU241 \\
PU242 \\
AM241 \\
AM242 \\
AM2 $21 M$ \\
AM243 \\
CM242 \\
CM243 \\
CM244 \\
CM245 \\
CM246 \\
CM247 \\
CM248
\end{tabular}

COHCEHTRATIOH $6.90427 \mathrm{E}-11$ (2) 4.11260E-15
$2.10099 \mathrm{E}-09$ 1. $30500 E-09$ $8.67373 E-43$

$1.64756 \mathrm{E}-04$

$1.64756 \mathrm{E}-04$

$1.67767 \mathrm{E}-06$

$1.05937 \mathrm{E}-06$

1.24443E-04

1. $41300 \mathrm{E}-09$

$5.05427 \mathrm{E}-06$

$3.23628 \mathrm{E}-09$

$3.25249 E-A 7$

1.36676E-0?

2.68427E-09

1. $03323 \mathrm{E}-09$

$2.63530 E-08$

$1.57522 \mathrm{E}-12$

1. $25655 \mathrm{E}-13$

. $25655 \mathrm{E}-13$

$1.54695 \mathrm{E}-1$ ?
$1.61544 \mathrm{E}-19$ 


\section{TABLE 8}

Chemical Composition of Stage 1/Stage 2 Glass Waste Form

\begin{tabular}{|c|c|c|c|}
\hline Compound & $h^{\prime} t \%$ & Compound & Wt \% \\
\hline $\mathrm{SiO}_{2}$ & 46.3 & Group B & .349 \\
\hline $\mathrm{Na}_{2} \mathrm{O}$ & 16.3 & $\mathrm{ThO}_{2}$ & .223 \\
\hline$B_{2} O_{3}$ & 10.9 & $\mathrm{Ca}_{3}\left(\mathrm{PO}_{4}\right)_{2}$ & .144 \\
\hline $\mathrm{Fe}_{2} \mathrm{O}_{3}$ & 5.90 & $\mathrm{Cr}_{2} \mathrm{O}_{3}$ & .109 \\
\hline $\mathrm{Li}_{2} \mathrm{O}$ & 4.25 & Group A & .102 \\
\hline $\mathrm{Al}_{2} \mathrm{O}_{3}$ & 3.25 & $\mathrm{ZnO}$ & .0927 \\
\hline $\mathrm{Fe}_{3} \mathrm{O}_{4}$ & 2.81 & $\mathrm{Cs}_{2} \mathrm{O}$ & .0639 \\
\hline $\mathrm{MgO}$ & 1.63 & $\mathrm{PbO}$ & .0402 \\
\hline Mno & 1.62 & $\mathrm{BaO}$ & .0625 \\
\hline Zeolite & 1.43 & $\mathrm{Cu}_{2} \mathrm{O}$ & .0315 \\
\hline $\mathrm{UZ}_{2}$ & 1.17 & $\mathrm{SrO}$ & .0285 \\
\hline $\mathrm{CaO}$ & 1.04 & $\mathrm{RuO}_{2}$ & .0231 \\
\hline $\mathrm{TiO}_{2}$ & .746 & $\mathrm{Y}_{2} \mathrm{O}_{3}$ & .0169 \\
\hline $\mathrm{NiO}$ & .607 & $\mathrm{CoO}$ & .0160 \\
\hline $\mathrm{ZrO}_{2}$ & .373 & $\mathrm{PuO}_{2}$ & .0141 \\
\hline $\mathrm{La}_{2} \mathrm{O}_{3}$ & .373 & $\mathrm{RhO}_{2}$ & .00489 \\
\hline
\end{tabular}

Group A: Tc, Se, Te, Rb, Mo

Group B: Ag, Cd, Cr, Pd, T1, La, Ce, Pr, Pm, Nd, $\mathrm{Sm}, \mathrm{Tb}, \mathrm{Sn}, \mathrm{Sb}, \mathrm{Co}, \mathrm{Zr}, \mathrm{Nb}, \mathrm{Eu}, \mathrm{Np}, \mathrm{Am}, \mathrm{Cm}$ 


\section{TABLE 9}

Isotopic Content of Stage 1/Stage 2 Glass Waste Form - C1/1b (FS-2-1)

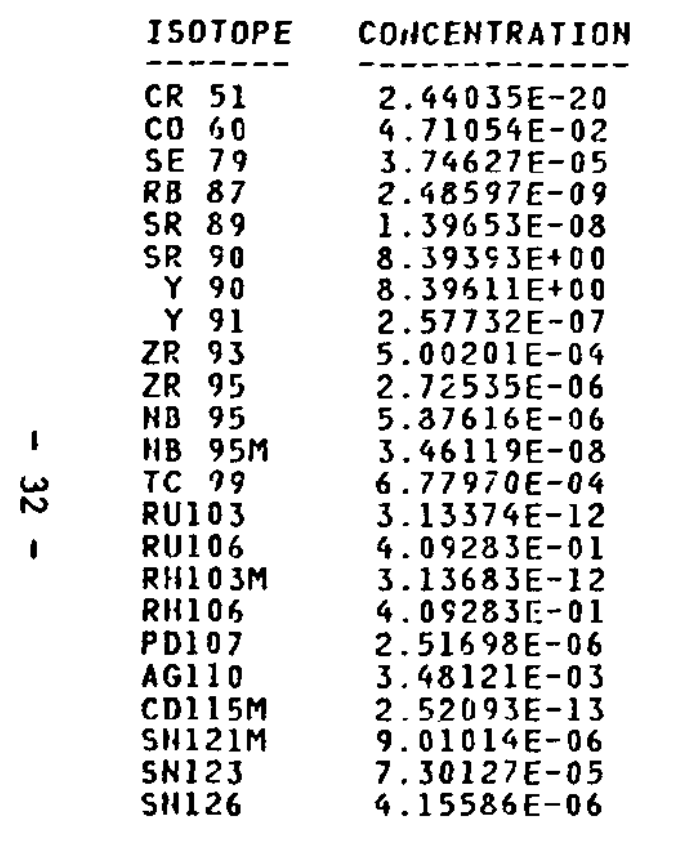

ISOTOPE
SB124
SB125
SB126
SB126M
TE125M
TE127
TE127M
TE129
TE129M
CS134
CS135
CS136
CS137
BA136M
BA137M
BA1 40
LA140
CE141
CE142
CE144
PR143
PR144
PRI $144 M$

\begin{tabular}{l} 
CONCENTRATION \\
\hline $1.96618 E-11$ \\
$2.32420 \mathrm{E}-01$ \\
$5.81320 \mathrm{E}-07$ \\
$4.15587 \mathrm{E}-06$ \\
$5.44657 \mathrm{E}-02$ \\
$2.37724 \mathrm{E}-05$ \\
$2.42699 \mathrm{E}-05$ \\
$6.00651 \mathrm{E}-16$ \\
$9.46020 \mathrm{E}-16$ \\
$3.70538 \mathrm{E}-02$ \\
$1.82563 \mathrm{E}-05$ \\
$1.55385 \mathrm{E}-45$ \\
$7.74874 \mathrm{E}+00$ \\
$4.97230 \mathrm{E}-46$ \\
$7.33030 \mathrm{E}+00$ \\
$5.76606 \mathrm{E}-44$ \\
$1.18811 \mathrm{E}-40$ \\
$9.86009 \mathrm{E}-15$ \\
$2.62469 \mathrm{E}-09$ \\
$2.70829 \mathrm{E}+00$ \\
$3.28787 \mathrm{E}-38$ \\
$2.70839 \mathrm{E}+00$ \\
$3.25000 \mathrm{E}-02$
\end{tabular}

\begin{tabular}{l} 
ISOTOPE \\
\hline ND144 \\
ND147 \\
PM147 \\
PM148 \\
PM143M \\
SM147 \\
SM148 \\
SH149 \\
SM151 \\
EU152 \\
EU154 \\
EU155 \\
EU156 \\
TB160 \\
TL206 \\
TL207 \\
TL208 \\
TL209 \\
U232 \\
U233 \\
U234 \\
U235
\end{tabular}

\section{CONCENTRATION}

$1.32303 \mathrm{E}-13$

$3.48495 \mathrm{E}-48$

$6.637565+00$

1. $90937 \mathrm{E}-14$

$2.76851 \mathrm{E}-13$

$5.25715 E-10$

$1.54710 \mathrm{E}-15$

$4.79554 \mathrm{E}-16$

$6.48524 \mathrm{E}-02$

$6.48524 E-02$

1. $04545 \mathrm{E}-03$

1. $71688 \mathrm{E}-01$

1. $35857 \mathrm{E}-01$

1. $44733 E-35$

$3.07319 \mathrm{E}-10$

1. $32408 E-21$

$1.86134 \mathrm{E}-11$

2. $90113 E-07$

1. $18706 \mathrm{E}-15$

$1.41090 \mathrm{E}-06$

$1.67292 \mathrm{E}-10$

4.41420 E-06

$1.45470 \mathrm{E}-08$

Activity

Decay Heat

Total Primary

Total Gamma
$4.60 \mathrm{E}+01 \mathrm{Ci} / \mathrm{lb}$

$9.94 \mathrm{E}-02$ watt $/ 1 \mathrm{~b}$

$3.03 \mathrm{E}-02 \mathrm{wat} / \mathrm{lb}$
ISOTOPE CONCENTRATION

U236 3.15518 E-07

U238 $8.01297 \mathrm{E}-03$

$4.77329 \mathrm{E}-12$

NP237 2.42729E-06

PU236 $\quad 1.71339 E-05$

PU237 I.25482E-15

PU238 $2.07114 \mathrm{E}-01$

$1.34981 \mathrm{E}-03$

PU240 1.23217E-03

PU241 2.31439E-O1

PU242 $1.64176 \mathrm{E}-06$

AMi241 2.93332E-03

$3.93022 E-06$

Al1242M $3.95059 E-06$

Al1243

CM242

C.1243

CM?44

CM245

CM246

CM247

CI1248

1. $58772 \mathrm{E}-06$

9.63765E-06

1. $52872 \mathrm{E}-06$

4. $48207 \bar{E}-05$

1. $22967 \mathrm{E}-09$

$1.46046 \mathrm{E}-10$

$1.73536 \mathrm{E}-16$

$1.87+85 E-16$ 
TABLE 10

\section{Chemical Compositions of Glass Frits*}

\begin{tabular}{|c|c|c|c|c|c|}
\hline \multirow[t]{2}{*}{ Oxide } & \multicolumn{5}{|c|}{ Frit Number } \\
\hline & $21 * \star$ & 22 & 211 & 411 & $131 \dagger$ \\
\hline $\mathrm{SiO}_{2}$ & 52.5 & 52.5 & 58.3 & 58.3 & 57.9 \\
\hline $\mathrm{Na}_{2} \mathrm{O}$ & 18.5 & 15.2 & 20.6 & 12.5 & 17.7 \\
\hline $\mathrm{TiO}_{2}$ & 10.0 & 10.0 & - & - & 1.0 \\
\hline $\mathrm{B}_{2} \mathrm{O}_{3}$ & 10.0 & 10.0 & 11.1 & 11.1 & 14.7 \\
\hline $\mathrm{Li}_{2} \mathrm{O}$ & 4.0 & 7.3 & 4.4 & 12.5 & 5.7 \\
\hline MgO & - & - & - & - & 2.0 \\
\hline $\mathrm{ZrO}_{2}$ & - & - & - & - & 0.5 \\
\hline $\mathrm{La}_{2} \mathrm{O}_{3}$ & - & - & - & - & 0.5 \\
\hline $\mathrm{CaO}$ & 5.0 & 5.0 & 5.6 & 5.6 & - \\
\hline
\end{tabular}

* Percent composition by weight.

** Frit used in leachability tests for Figures 5 to 8.

$\dagger$ Current reference frit is Frit 131. 
TABLE 11

Physical Properties of Glass Waste Forms

Value

Thermal Conductivity

at $100^{\circ} \mathrm{C}$

$0.55 \mathrm{Btu} /(\mathrm{hr})(\mathrm{ft})\left({ }^{\circ} \mathrm{F}\right)$

Heat Capacity at $100^{\circ} \mathrm{C}$

$0.22 \mathrm{cal} /(\mathrm{g})\left({ }^{\circ} \mathrm{C}\right)$

Fractional Therma 1

Expansion*

$1.22 \times 10^{-5} /{ }^{\circ} \mathrm{C}$

Young's Modulus**

$9 \times 10^{6} \mathrm{psi}$

Tensile strength

$9 \times 10^{3} \mathrm{psi}$

Compressive Strength

$1 \times 10^{5}$ psi

Poisson's Ratiof

0.2

Density at $100^{\circ} \mathrm{C} *$

$2.75 \mathrm{~g} / \mathrm{cc}$

Softening Point*

$502^{\circ} \mathrm{C}$

* Experimentally determined for Frit 131 glasses.

** Young's modulus, or the modulus of elasticity, measures the stiffness of the material.

+ Poisson's ratio is equivalent to the ratio of equatorial to axial strain under an applied axial stress. 
TABLE 12

\section{Composition of SRP Simulated Waste Glasses*}

\begin{tabular}{|c|c|c|c|c|c|c|}
\hline \multirow[t]{2}{*}{ Component } & \multicolumn{2}{|c|}{$\begin{array}{c}\text { Stage } 1 \text { Composite, } \\
\text { TDS-3A }\end{array}$} & \multicolumn{2}{|c|}{$\mathrm{High}-\mathrm{Fe}$} & \multicolumn{2}{|c|}{$\mathrm{High}-\mathrm{Al}$} \\
\hline & Wt. Frac. & Mole Frac. & Wt. Frac. & Mole Frac. & Wt. Frac. & Mole Frac. \\
\hline $\mathrm{SiO}_{2}$ & 0.422 & 0.4670 & 0.418 & 0.466 & 0.423 & 0.4596 \\
\hline $\mathrm{B}_{2} \mathrm{O}_{3}$ & 0.104 & 0.0990 & 0.104 & 0.1001 & 0.104 & 0.0975 \\
\hline $\mathrm{Na}_{2} \mathrm{O}$ & 0.134 & 0.1440 & 0.143 & 0.1546 & 0.140 & 0.1474 \\
\hline $\mathrm{Li}_{2} \mathrm{O}$ & 0.040 & 0.0890 & 0.040 & 0.0897 & 0.040 & 0.0874 \\
\hline $\mathrm{CaO}$ & 0.011 & 0.0130 & 0.012 & 0.0143 & 0.003 & 0.0035 \\
\hline MgO & 0.014 & 0.023 & 0.014 & 0.0230 & 0.014 & 0.0227 \\
\hline $\mathrm{TiO}_{2}$ & 0.007 & 0.0058 & 0.007 & 0.0059 & 0.007 & 0.0057 \\
\hline $\mathrm{La}_{2} \mathrm{O}_{3}$ & 0.004 & 0.0008 & 0.004 & 0.0008 & 0.004 & 0.0008 \\
\hline $\mathrm{ZrO}_{2}$ & 0.004 & 0.0022 & 0.004 & 0.0022 & 0.004 & 0.0021 \\
\hline $\mathrm{Fe}_{2} \mathrm{O}_{3}$ & 0.142 & 0.0592 & 0.177 & 0.0743 & 0.041 & 0.0168 \\
\hline $\mathrm{MnO}_{2}$ & 0.041 & 0.0314 & 0.012 & 0.0093 & 0.034 & 0.0255 \\
\hline Zeolite & 0.031 & 0.0299 & 0.029 & 0.0290 & 0.031 & 0.0302 \\
\hline $\mathrm{Al}_{2} \mathrm{O}_{3}$ & 0.029 & 0.0192 & 0.004 & 0.0026 & 0.148 & 0.0948 \\
\hline $\mathrm{NiO}$ & 0.017 & 0.0151 & 0.030 & 0.0269 & 0.006 & 0.0052 \\
\hline $\mathrm{Na}_{2} \mathrm{SO}_{4}$ & 0.002 & 0.00937 & 0.002 & 0.0009 & 0.002 & 0.0009 \\
\hline
\end{tabular}

* Stage 1 Composite TDS-3A: Composition shown is the basis used for the calculation of physical properties. The composition is similar to the reference composition shown in Table 4, "Chemical Composition of Stage 1 Glass Waste Form."

High-Fe: Similar to stage 1 Composite TDS-3A, except $\mathrm{Fe}_{2} \mathrm{O}_{3}$ is 17.7 wt $\%$ instead of 14.2 wt $\%$.

High-A1: Similar to Stage 1 Composite $\mathrm{TDS}-3 \mathrm{~A}$, except $\mathrm{Al}_{2} \mathrm{O}_{3}$ is 14.8 wt \% instead of 2.9 wt $\%$. 
TABLE 13

Heat Capacities for SRP Simulated Waste Glasses

\begin{tabular}{|c|c|c|}
\hline \multirow[b]{2}{*}{ Temp, ${ }^{\circ} \mathrm{C}$} & \multicolumn{2}{|c|}{$\begin{array}{l}\text { Stage } 1 \text { Composite, } \\
\mathrm{Cal} /(\mathrm{g})\left({ }^{\circ} \mathrm{C}\right)\end{array}$} \\
\hline & $\mathrm{C}_{\mathrm{pm}}$ & $\mathrm{C}_{\mathrm{pt}}$ \\
\hline 0 & 0.186 & 0.186 \\
\hline 100 & 0.213 & 0.237 \\
\hline 200 & 0.234 & 0.271 \\
\hline 300 & 0.251 & 0.296 \\
\hline 400 & 0.264 & 0.314 \\
\hline 500 & 0.276 & 0.328 \\
\hline 600 & 0.285 & 0.338 \\
\hline 700 & 0.293 & 0.346 \\
\hline 800 & 0.300 & 0.353 \\
\hline 900 & 0.307 & 0.359 \\
\hline 950 & 0.309 & 0.361 \\
\hline 1000 & 0.312 & 0.363 \\
\hline 1025 & 0.313 & 0.364 \\
\hline 1050 & 0.315 & 0.365 \\
\hline 1075 & 0.316 & 0.366 \\
\hline 1100 & 0.317 & 0.367 \\
\hline 1125 & 0.318 & 0.368 \\
\hline 1150 & 0.319 & 0.369 \\
\hline 1175 & $0.32 n$ & 0.369 \\
\hline 1200 & 0.321 & 0.370 \\
\hline 1250 & 0.323 & 0.372 \\
\hline 1300 & 0.325 & 0.373 \\
\hline
\end{tabular}

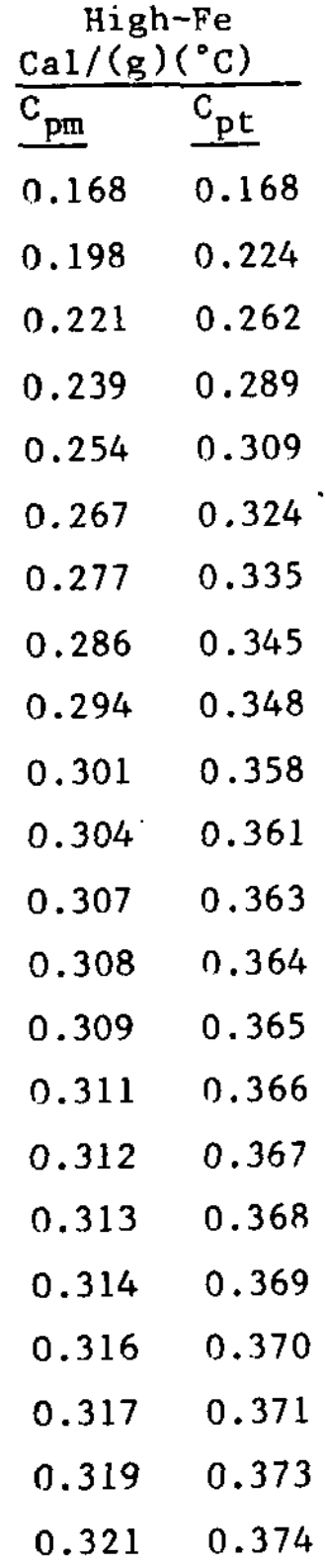

\begin{tabular}{ll}
\multicolumn{2}{c}{$H i g h-\mathrm{Al}$} \\
$\frac{\mathrm{Cal} /(\mathrm{g})}{\mathrm{C}_{\mathrm{pm}}}$ & ${ }^{\mathrm{C}_{\mathrm{pt}}}$ \\
\hline 0.173 & 0.173 \\
0.201 & 0.225 \\
0.223 & 0.261 \\
0.240 & 0.286 \\
0.254 & 0.305 \\
0.266 & 0.319 \\
0.275 & 0.330 \\
0.284 & 0.339 \\
0.291 & 0.346 \\
0.298 & 0.352 \\
0.300 & 0.354 \\
0.303 & 0.356 \\
0.304 & 0.357 \\
0.306 & 0.358 \\
0.307 & 0.359 \\
0.308 & 0.360 \\
0.309 & 0.361 \\
0.310 & 0.362 \\
0.312 & 0.363 \\
0.313 & 0.364 \\
0.315 & 0.365 \\
0.317 & 0.366 \\
& \\
0.356
\end{tabular}

Cpm: Mean heat capacity referenced to $0^{\circ} \mathrm{C}$ Cpt: True heat capacity at the indicated temperature 
TABLE 14

\section{Densities of SRP Simulated Waste Glasses}

4

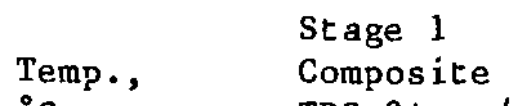

${ }^{\circ} \mathrm{C}$

TDS- $3 \mathrm{~A}, \mathrm{~g} / \mathrm{cm}^{3} \quad \mathrm{High}-\mathrm{Fe}, \mathrm{g} / \mathrm{cm}^{3} \quad \mathrm{High}-\mathrm{Al}, \mathrm{g} / \mathrm{cm}^{3}$

20

2.750

2.743

2.735

2.726

2.718

2.713

2.672

2.575

2.481

2.391

2.305

2.223

2.202

2.183

2.163

2.143

2.124

2.105

2.086

2.068
2.820

2.813

2.804

2.795

2.786

2.781

2.721

2.607

2.499

2.396

2.298

2.204

2.181

2.159

2.137

2.115

2.093

2.072

2.051

2.031
2.60

2.593

2.585

2.577

2.569

2.565

2.520

2.432

2.348

2.266

2.188

2.113

2.094

2.076

2.058

2.040

2.023

2.006

1.988

1.971
1200

* The transition temperature, $T_{r}$, is different for each type of glass. 
TABLE 15

Index of Refraction for SRP Simulated Waste Glasses*

Index of Refraction

Type of Waste at $\lambda=4860 \AA$

Stage 1

Composite TDS-3A

1.662

$\mathrm{High}-\mathrm{Fe}$

1.6971

High-Al

1.577

* At room temperature. 
TABLE 16

Thermal Conductivity of SRP Simulated Waste Glasses*

H

$$
\mathrm{K}_{\mathrm{eff}}
$$

\begin{tabular}{l} 
Temp., Stage 1 \\
${ }^{\circ} \mathrm{C}$ \\
\hline
\end{tabular}

0

0.4893

0.4670

0.5389

100

0.5616

0.5479

0.5655

200

0.6339

0.6288

0.5921

300

0.7062

0.7097

0.6187

400

0.7785

0.7906

0.6453

500

0.8508

0.8715

0.6719

600

0.9231

0.9524

0.6985

670

0.9737

1.009

0.7171

685

1.0105

1.026

0.7211

700

1.044

1.060

0.7251

800

1.313

1.317

1.054

900

1.660

1.646

1.525

1000

2.085

2.045

2.12

1025

2.200

1050

2.33

1075

2.45

.1100

2.58

1125

2.71

2.156

2.29

2.270

2.47

2.39

2.65

2.51

2.84

2.64

3.03

1150

2.85

2.77

3.22

1175

2.99

1200

3.14

2.90

3.43

3.03

3.64

* Btu/(hr)(ft)( $\left.{ }^{\circ} F\right)$ 


\section{TABLE 17}

Principal Metal Ions in Washed, Dried Sludges

from SRP Tanks $13 \mathrm{H}$ and $16 \mathrm{H}^{*}$

\begin{tabular}{lll} 
Ions & \multicolumn{2}{c}{ Wt $\%$} \\
\cline { 2 - 3 } & Tank 13H & Tank 16H \\
$\mathrm{Fe}$ & 25.57 & 13.91 \\
$\mathrm{Al}$ & 8.70 & 16.61 \\
$\mathrm{Mn}$ & 7.85 & 2.59 \\
$\mathrm{U}$ & 4.18 & 4.49 \\
$\mathrm{Na}$ & 2.58 & 2.19 \\
$\mathrm{Sr}$ & $3.50 * *$ & Not determined \\
$\mathrm{Ca}$ & 1.76 & 2.87 \\
$\mathrm{Hg}$ & 2.32 & 2.80 \\
$\mathrm{Ni}$ & 0.45 & 0.30 \\
&
\end{tabular}


TABLE 18

DWPF Reference Canister Heat Generation

Years

Watts

4

Stage 1 Stage 1/Stage 2

5

416

423

10

257

292

15

224

256

20

199

228

25

177

203

30

159

181

35

142

162

40

128

145

50

103

117

75

62

69

100

39

42

200

10

8.7

300

4.5

3.5

400

2.6

2.0

500

1.8

1.3

750

0.99

0.75

1000

0.76

0.57 
TABLE 19

Reference Glass Waste Form Surface Temperature*

Watts $\quad \stackrel{\circ}{ }$

$500 \quad 48$

$1000 \quad 57$

* Reference DWPF waste form, $2 \mathrm{ft} \times 7 \mathrm{ft} \times 7 \mathrm{in.}$, 165 gallons of waste glass containing $28 \%$ sludge oxides, and ambient air convection cooling. 


\section{TABLE 20}

Radiation from Reference Canister of Stage 1/Stage 2 Glass*

\begin{tabular}{ll}
$\begin{array}{l}\text { Distance from } \\
\text { Surface, cm }\end{array}$ & \multicolumn{2}{l}{ Rem/hr } \\
\hline 1 & $2.48 \mathrm{E} 04$ \\
10 & $1.82 \mathrm{E} 04$ \\
30 & $1.06 \mathrm{E} 04$ \\
90 & $3.31 \mathrm{E} 03$ \\
180 & $1.18 \mathrm{E} 03$ \\
200 & $9.98 \mathrm{E} 02$ \\
210 & $9.07 \mathrm{E} 02$ \\
500 & $1.85 \mathrm{E} 02$ \\
1000 & $4.81 \mathrm{E} 01$ \\
5000 & $1.97 \mathrm{E} 00$
\end{tabular}

* 5-yr-old sludge plus 15-yr-old supernate. 
TABLE 21

\section{Source Terms for Stage 1/Stage 2 Glass}

\begin{tabular}{|c|c|}
\hline $\begin{array}{l}\text { Energy, } \\
\mathrm{keV}\end{array}$ & Phot./Sec/Canister* \\
\hline $70-100$ & $5.158 \mathrm{E} \quad 12$ \\
\hline $100-150$ & 3.604 E 13 \\
\hline $150-300$ & $2.163 \mathrm{E} 12$ \\
\hline $300-450$ & $9.149 \mathrm{E} 12$ \\
\hline $450-700$ & 8.344 E 14 \\
\hline $700-1000$ & 4.535 E 12 \\
\hline $1000-1500$ & $1.365 \mathrm{E} 13$ \\
\hline $1500-2000$ & $1.258 \mathrm{E} 11$ \\
\hline $2000-2500$ & 2.463 E 12 \\
\hline $2500-3000$ & 4.889 E 9 \\
\hline
\end{tabular}

* Based upon a glass volume of 165 gallons. 
"

FIGURES

$-45-$ 


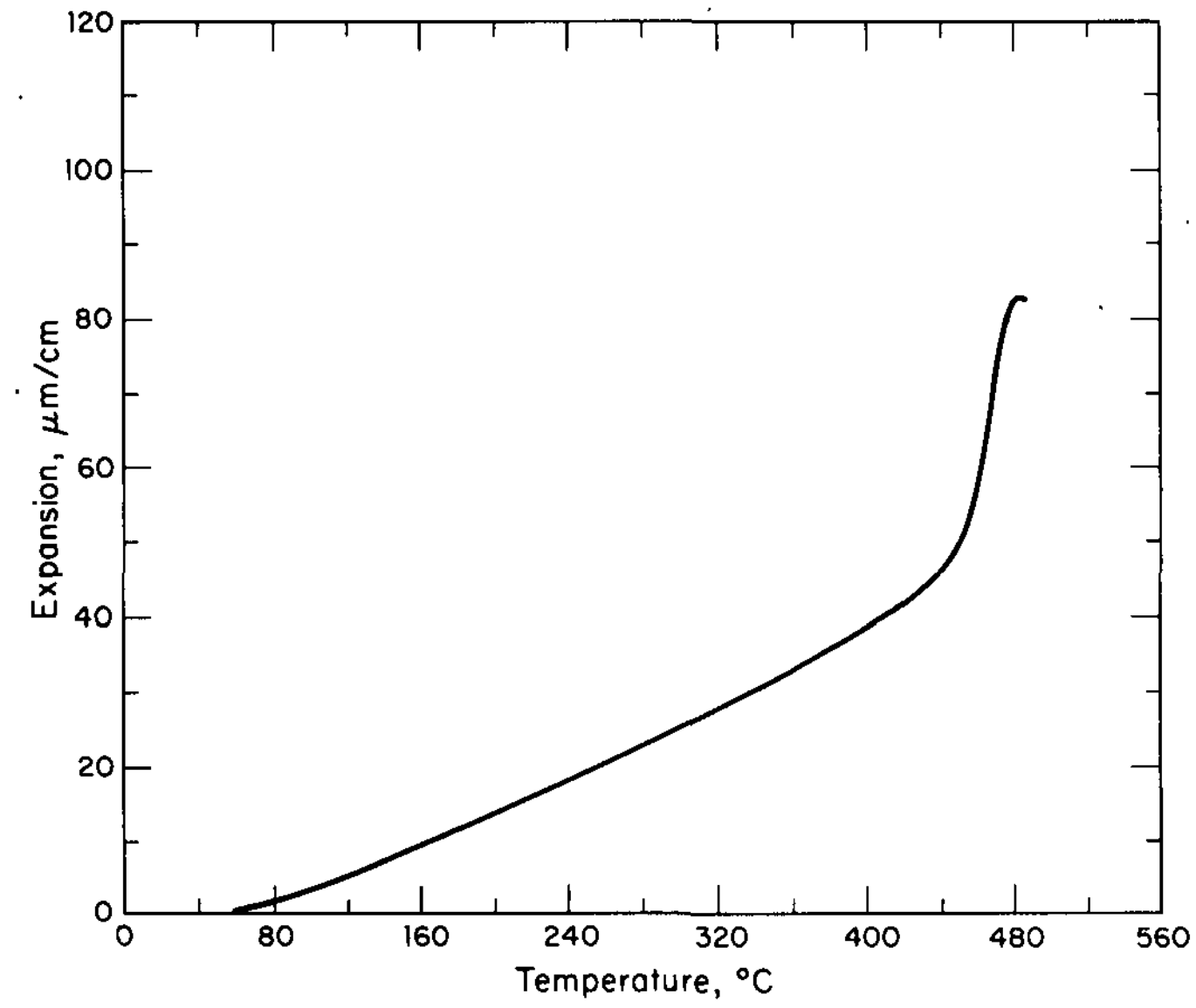

FIGURE 1. Thermal Expansion Data for 28 Percent Composite sludge Plus Frit 131 


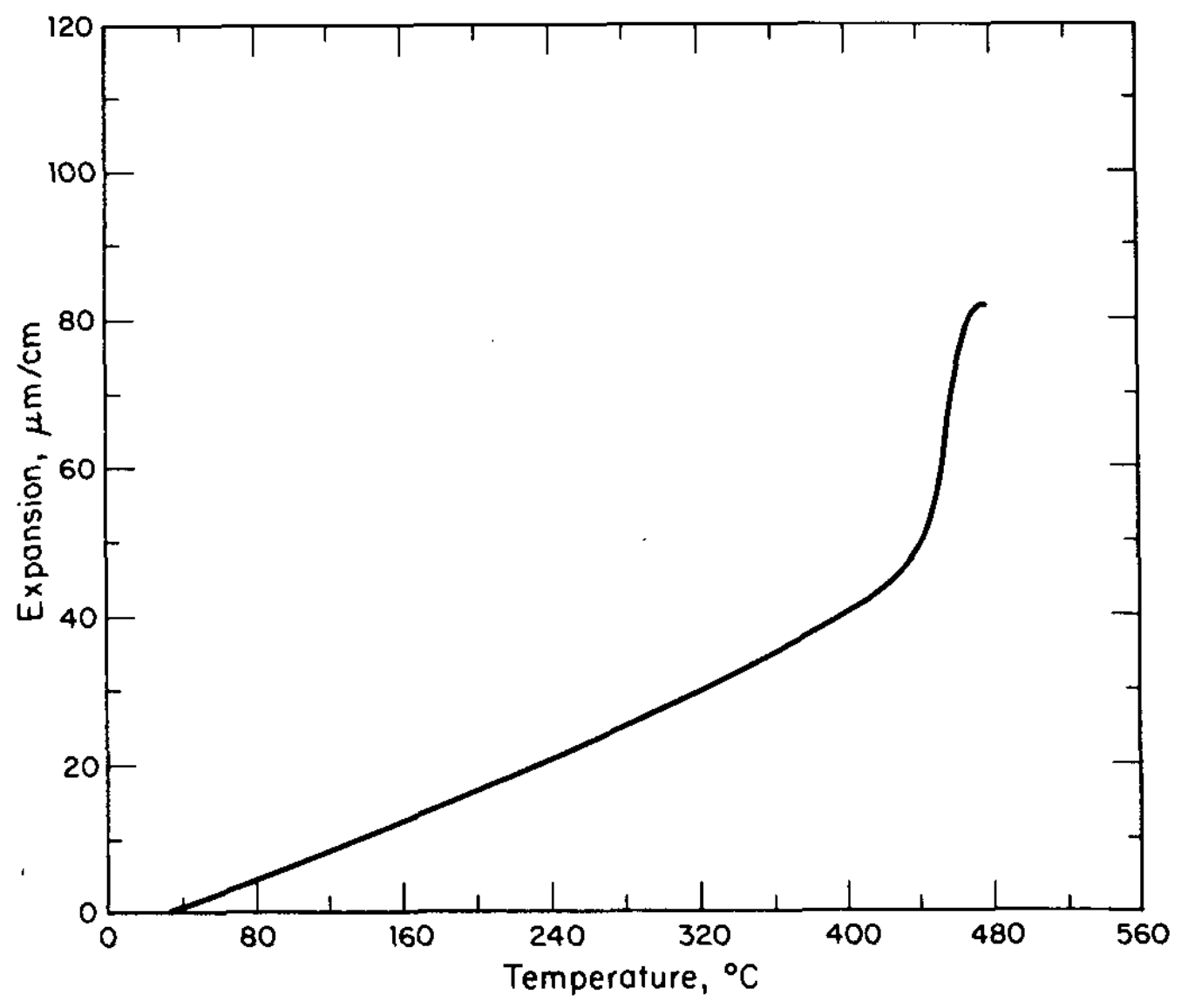

FIGURR 2. Thermal Expansion Data for 20 Percent High-Iron 


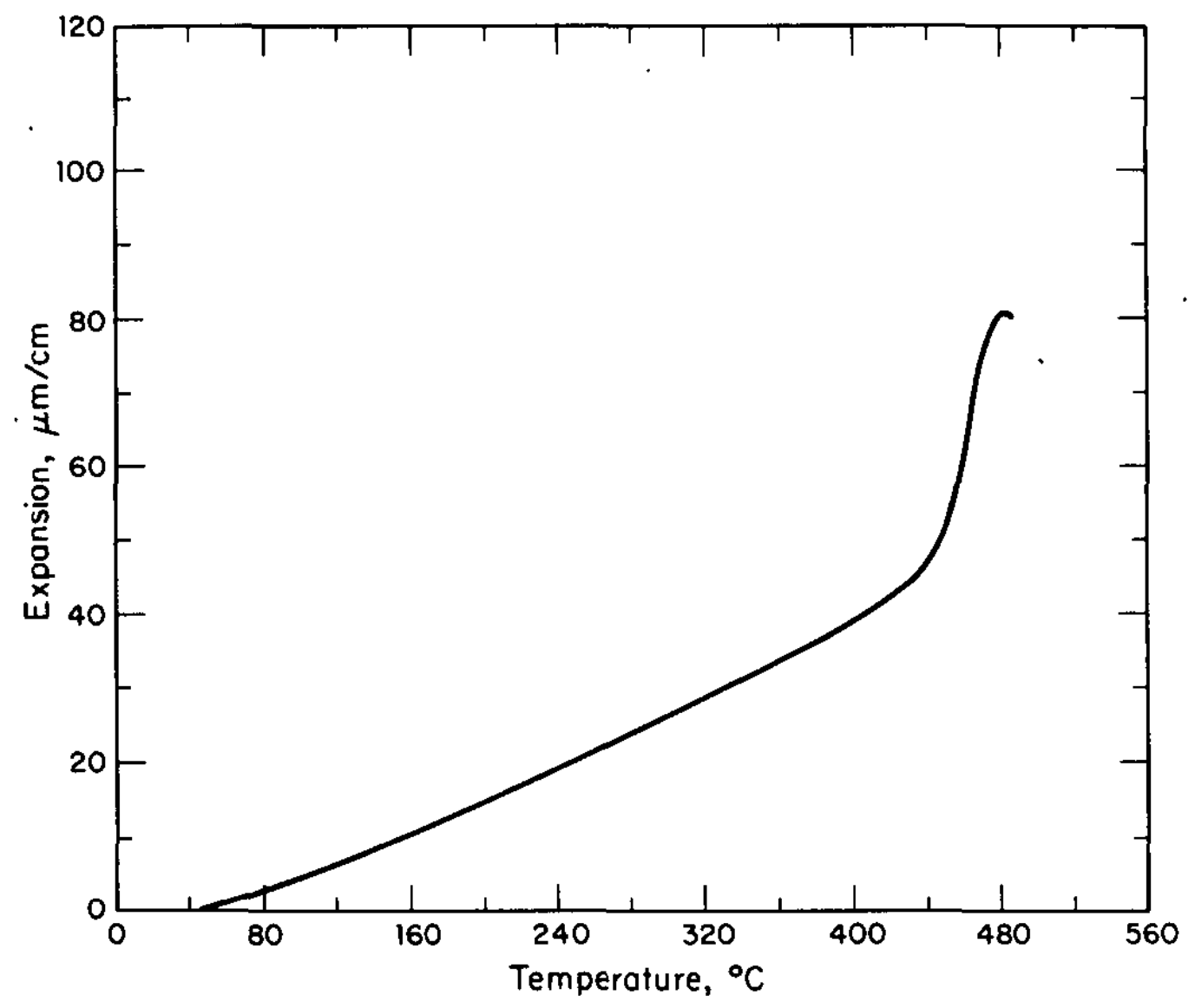

FIGURE 3. Thermal Expansion Data for 20 Percent High-Aluminum 


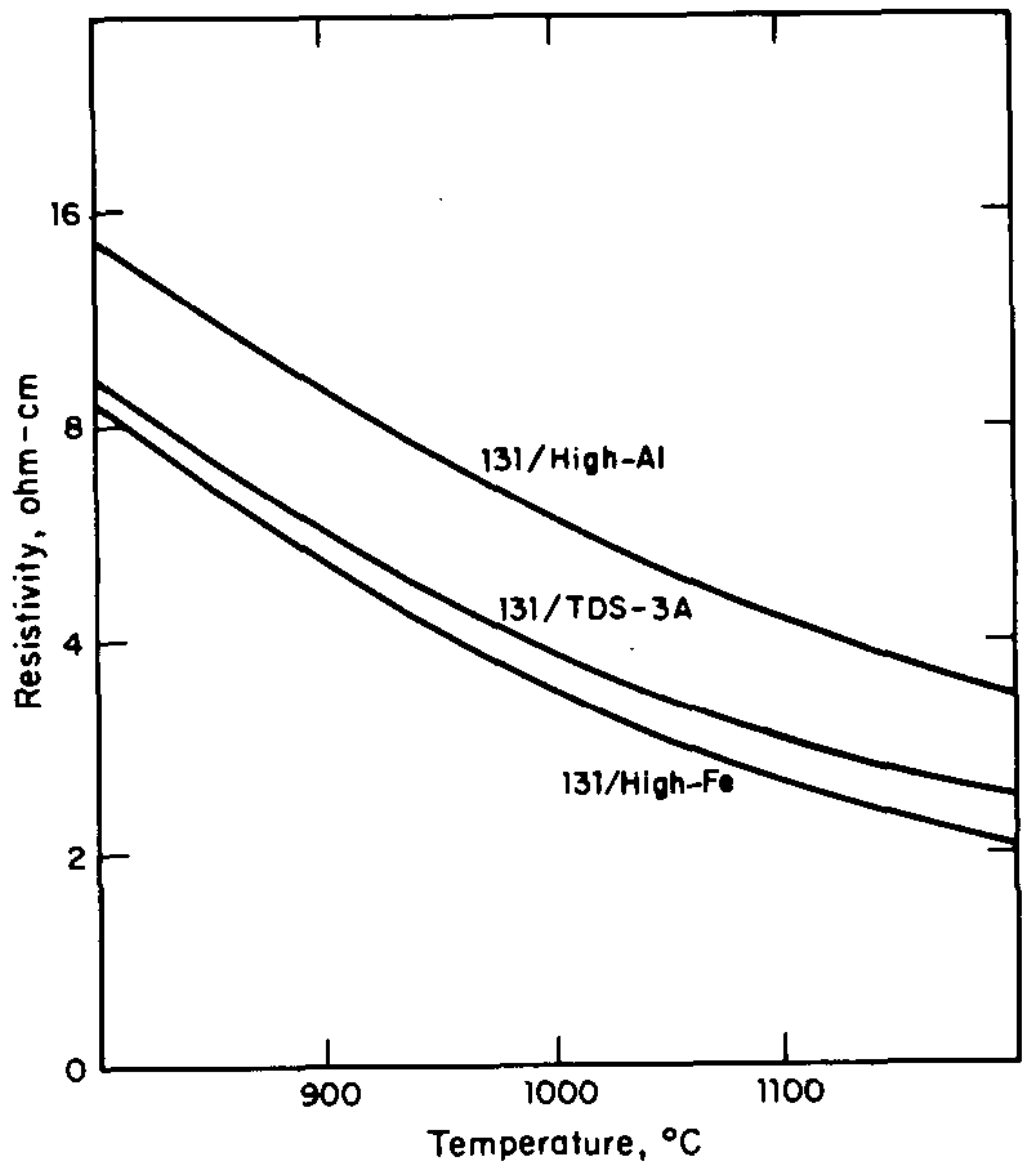

FIGURE 4. Resistivity of Frit 131/Waste Glasses 


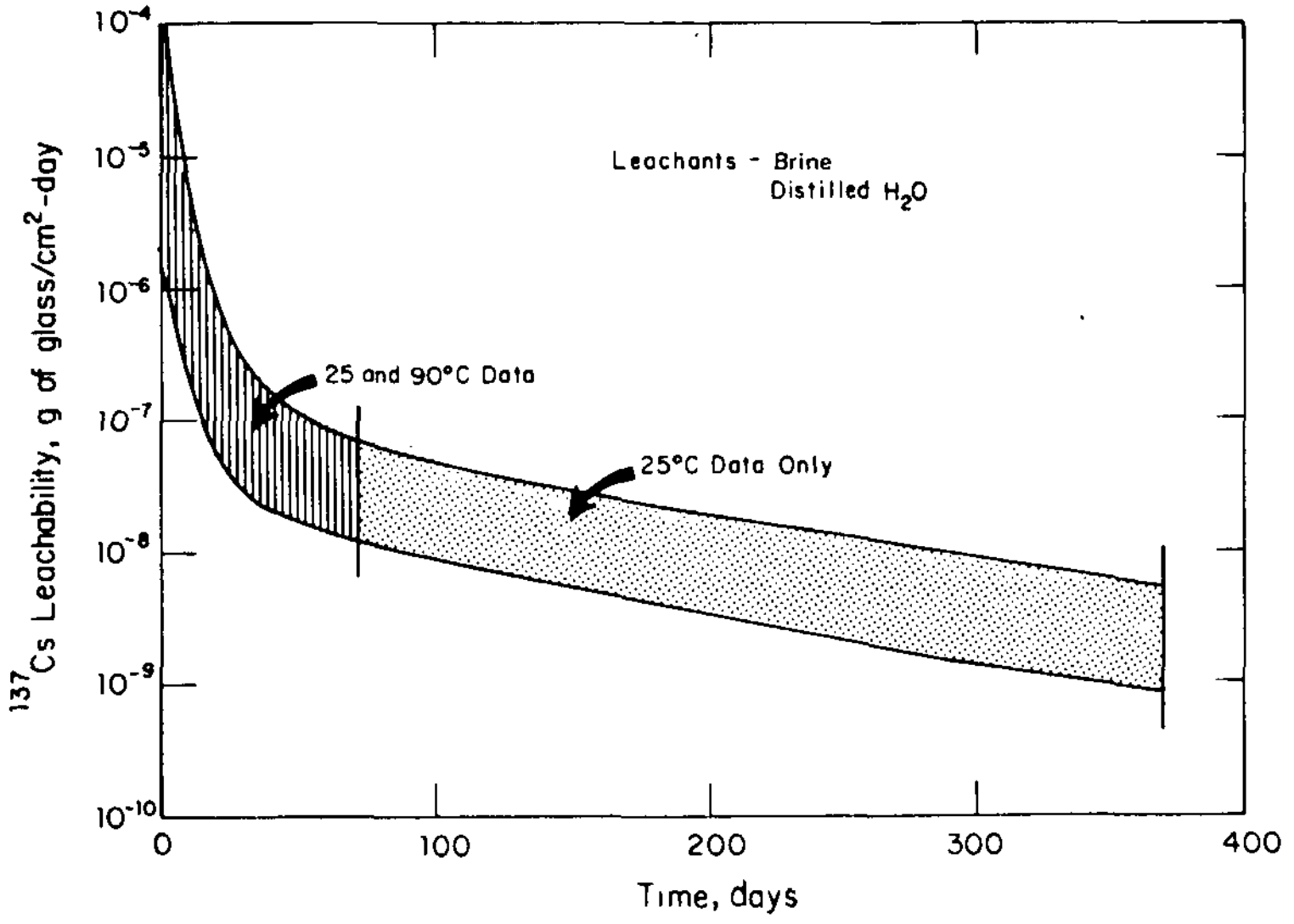

FIGURE 5. Published Leach Rates of SRP Glasses 


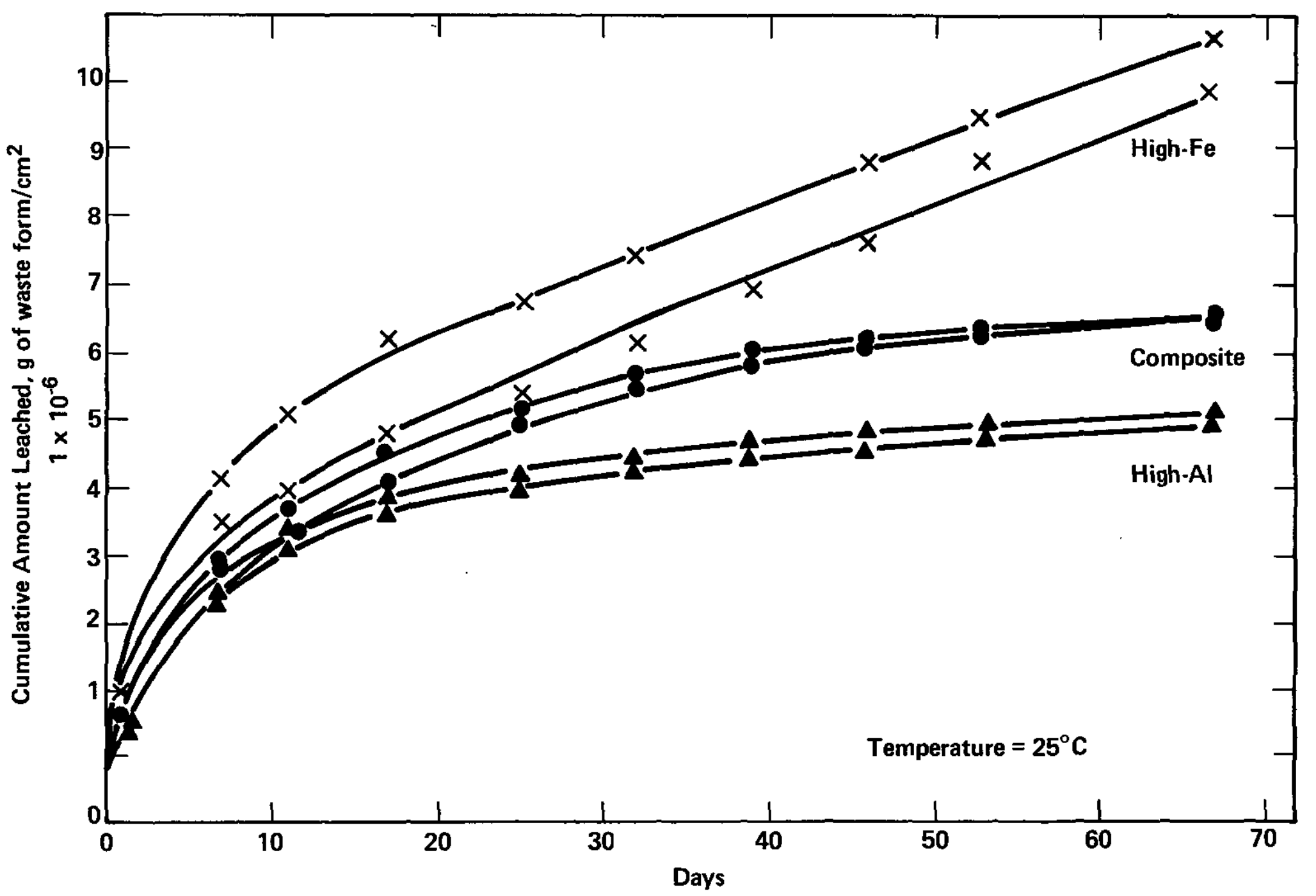

FIGURE 6. Cumulative Leaching of Frit 21-Simulated SRP Sludge Glass in Brine Based on ${ }^{137} \mathrm{Cs}$ 


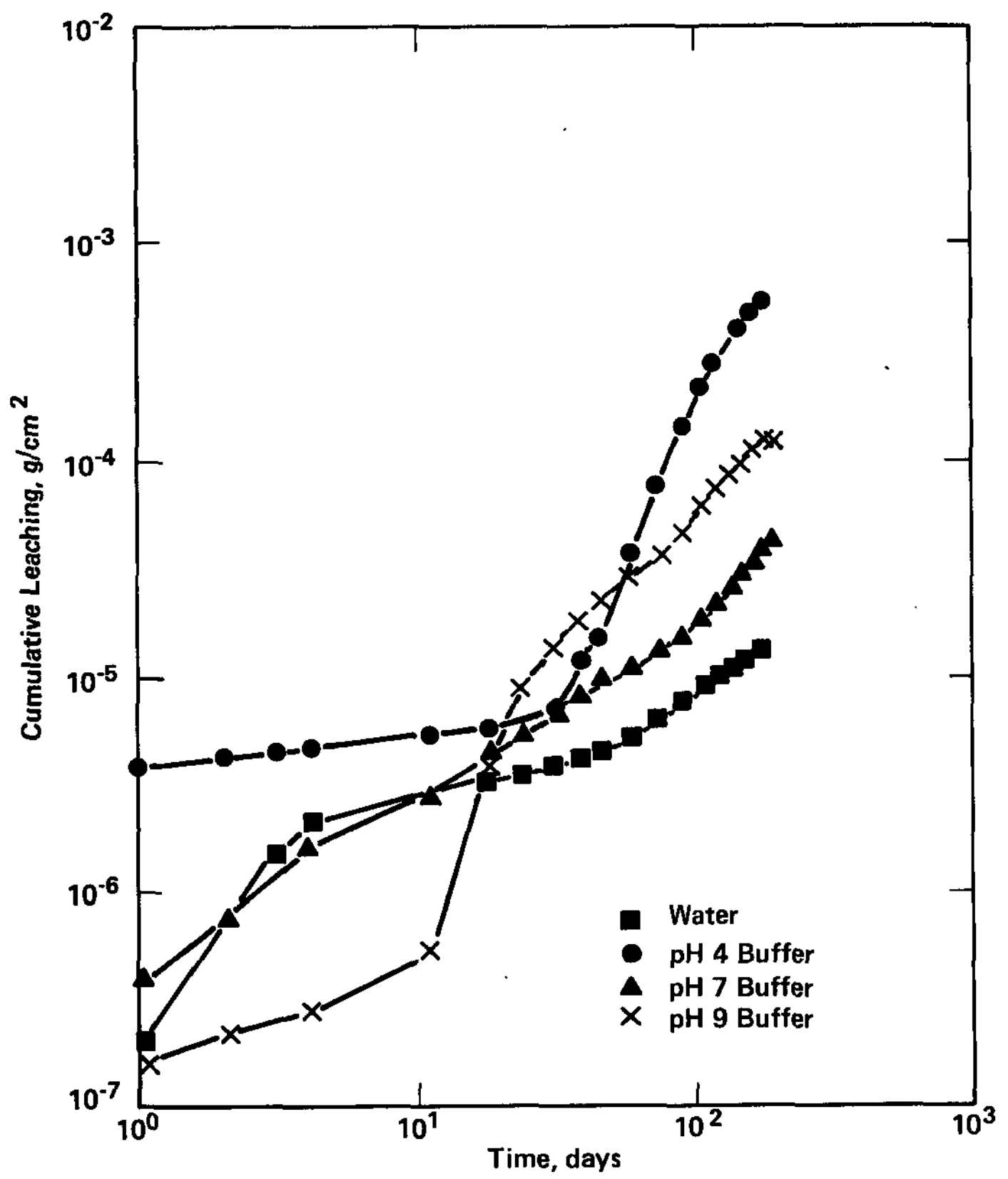

FIGURB 7. Cumulative Leaching of Frit 21-SRP Waste Tank No. 13 Glass Based on ${ }^{90} \mathrm{Sr}$ 
$\because$

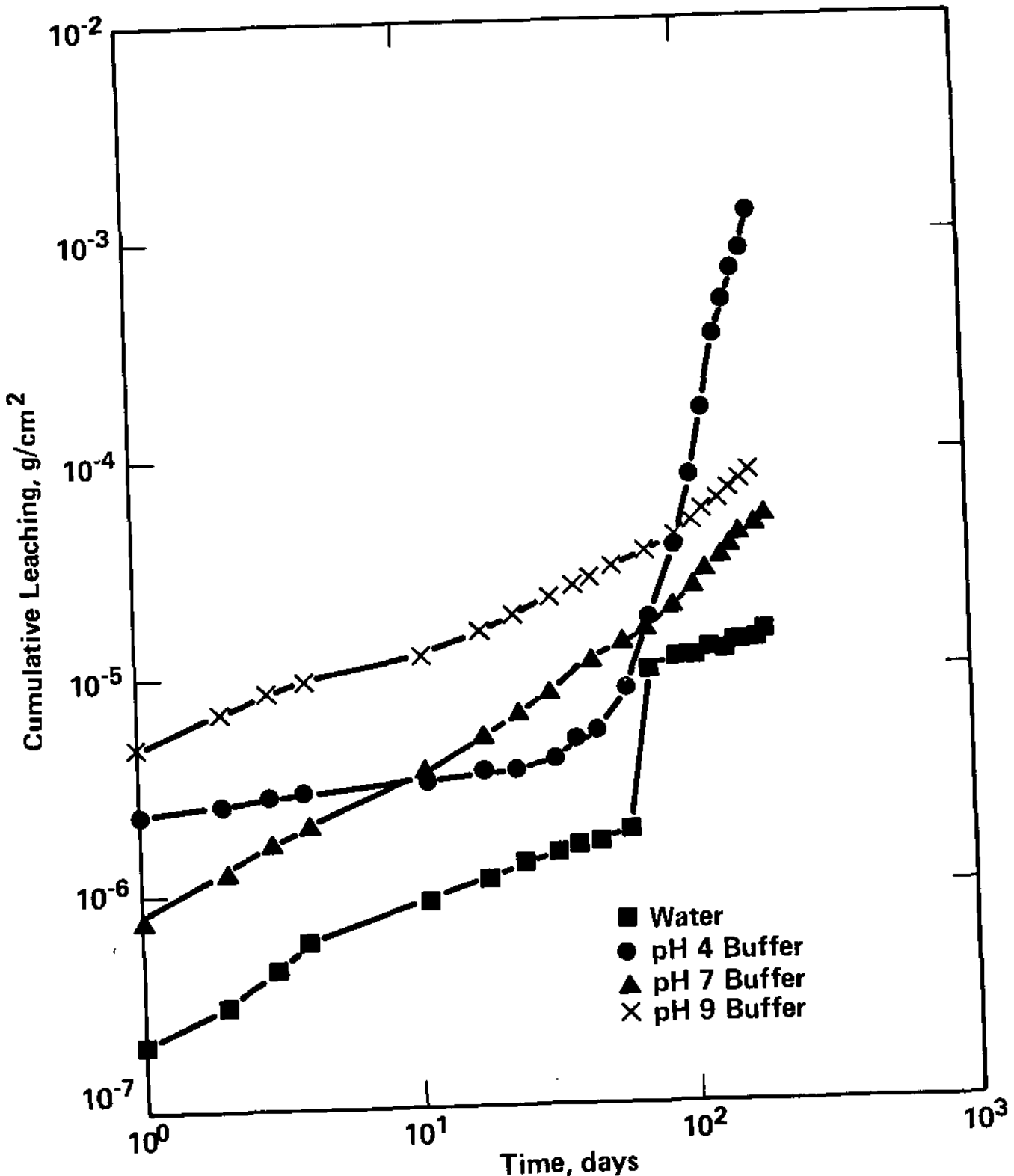

FIGURE 8. Cumulative Leaching of Frit 21-SRP Waste Tank No. 16 Glass Based on ${ }^{90} \mathrm{Sr}$ 

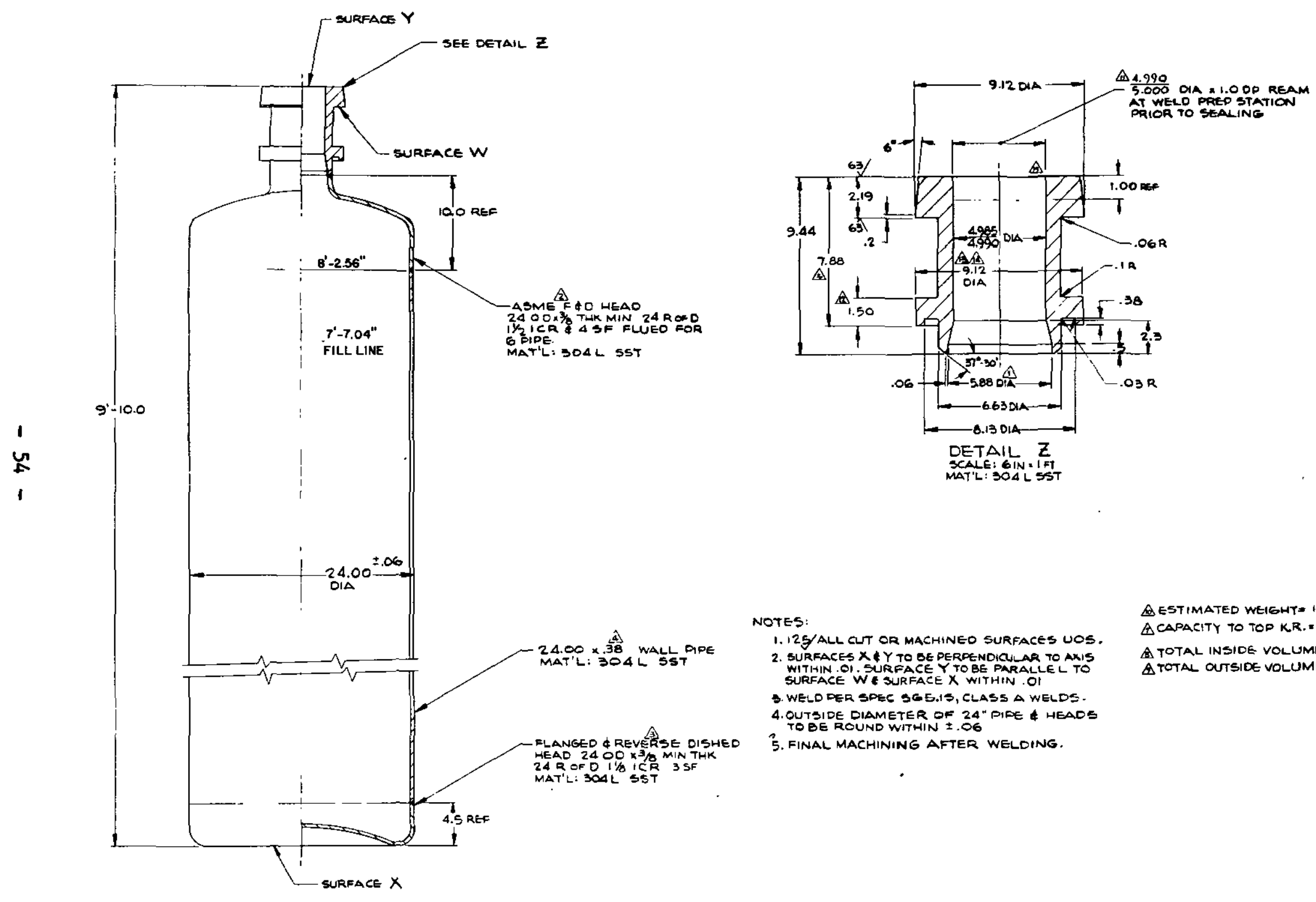

FIGURE 9. Canister Drawing

\section{NOTES}

1.125 ALLL CUT OR MACHINEO SURFACES UOS. 2. SURFACES $X$ HY TO BE PERPENDICU AR TO AX WITHIN O1 SURFACE Y TO BE PARALLEL TO WELD PER SPEE SG5.1S, CLASS A WELDS

4. OUTSIDE DIAMETER OF 24 "PIFE 4 HEAOS

Final machining after weloing.
QESTIMATED WEIGHT 1000 ACAPACITY TO TOD KR. $=24.9$ CU IT A TOTAL INSIDE VOLUME $=25.7$ oU $\triangle$ TOTAL OUSIOE VOLUME 27.7 CUFT 

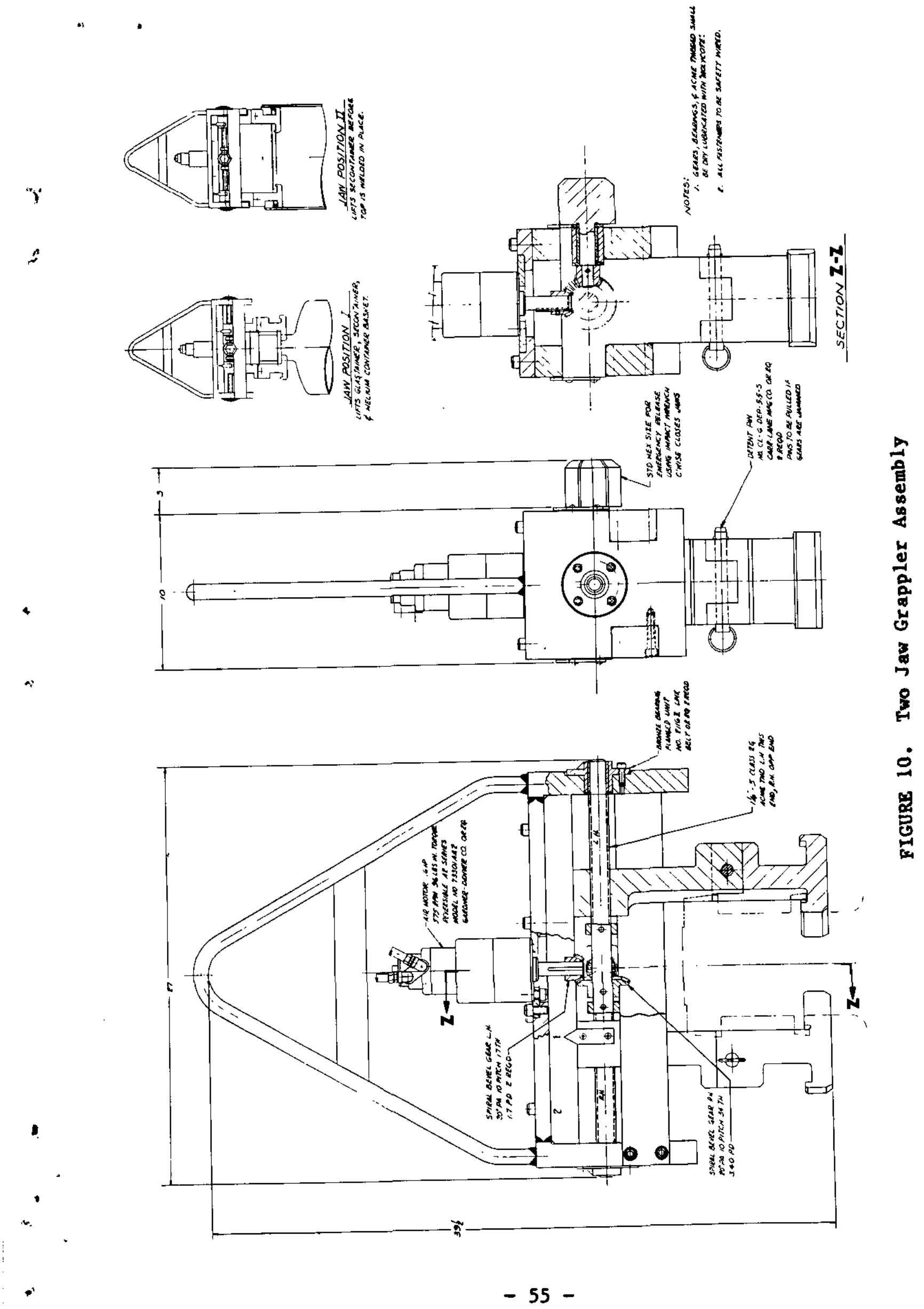


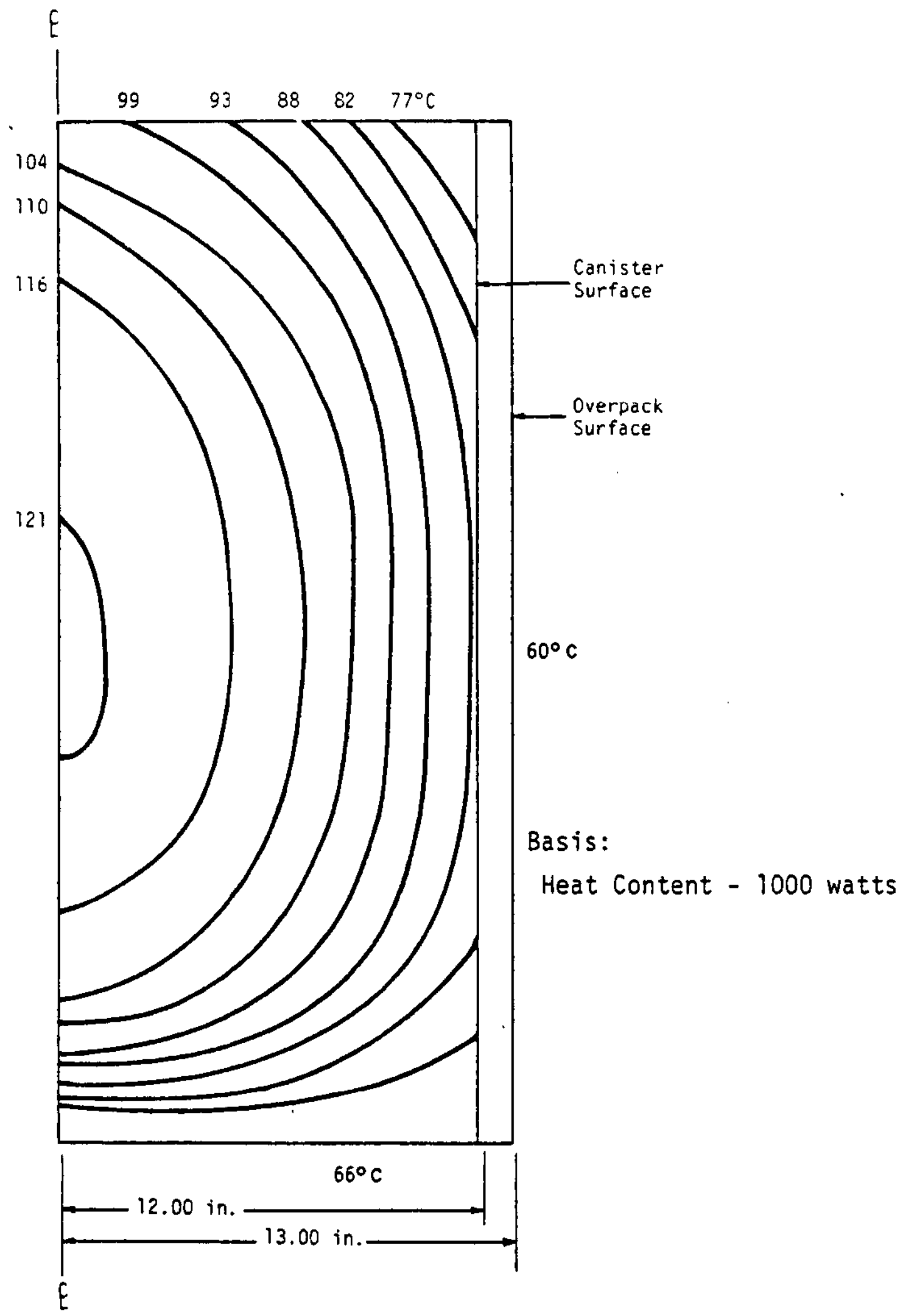

FIGURE 11. Canister Isotherms at Steady State 